\title{
Spatio-temporal evolution of strain accumulation derived from multi-scale observations of Late Jurassic rifting in the northern North Sea: A critical test of models for lithospheric extension
}

\author{
PATIENCE COWIE ${ }^{\mathrm{a}}$ JOHN UNDERHILL ${ }^{\mathrm{a}}$ MARK BEHN $^{\mathrm{b}, \mathrm{c}}$ \\ JIAN LIN $^{c}$ CAROLINE GILL $^{\mathrm{a}}$

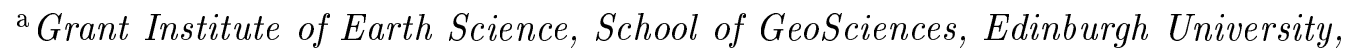 \\ Edinburgh EH9 3JW, UK \\ ${ }^{\mathrm{b}}$ Department of Terrestrial Magnetism, Carnegie Institution of Washington, \\ Washington, DC 20015, USA \\ ${ }^{\mathrm{c}}$ Department of Geology and Geophysics, Woods Hole Oceanographic Institution, \\ Woods Hole, MA 02543, USA
}

\begin{abstract}
We integrate observations of lithospheric extension over a wide range of spatial and temporal scales within the northern North Sea basin and critically review the extent to which existing theories of lithospheric deformation can account for these observations. Data obtained through a prolonged period of hydrocarbon exploration and production has yielded a dense and diverse data set over the entire Viking Graben and its flanking platform areas. These data show how syn-rift accommodation within the basin varied in space and time with sub-kilometer-scale spatial resolution and a temporal resolution of 2-3 Myr. Regional interpretations of 2D seismic reflection, refraction and gravity data for this area have also been published and provide an image of total basin wide stretching for the entire crust. These image data are combined with published strain rate inversion results obtained from tectonic subsidence patterns to constrain the spatio-temporal evolution of strain accumulation throughout the lithosphere during the 40 Myr (170-130 Ma) period of Late Jurassic extension across this basin. For the first 25-30 Myr, strain localisation dominated basin development with strain rates at the eventual rift axis increasing while strain rates over the flanking areas declined. As strain rates across the whole basin were consistently very low $\left(<3 \times 10^{-16} \mathrm{~s}^{-1}\right)$, thermally induced strength loss can not explain this phenomenon. The strain localisation is manifest in the near-surface by a systematic migration of fault activity. The pattern and timing of this migration are inconsistent with flexural bending stresses exerting an underlying control, especially when estimates of flexural rigidity for this area are
\end{abstract}

Preprint submitted to Elsevier Science 31 January 2005 
considered. The best explanation for what is observed in this time period is a coupling between near-surface strain localisation, driven by brittle (or plastic) failure, and the evolving thermal structure of the lithosphere. We demonstrate this process using a continuum mechanics model for normal fault growth that incorporates the strain rate-dependence of frictional strength observed in laboratory studies. During the final $10 \mathrm{Myr}$ of basin formation, strain accumulation was focused within the axis and strain rates declined rapidly. Replacement of weak crust by stronger mantle material plus crustal buoyancy forces can adequately explain this decline.

Key words:

Lithospheric extension, strain accumulation, normal faulting, numerical modelling, basin formation

PACS:

\section{Introduction}

Extensional basin geometry, and the sedimentary sequences that fill the basin, record the amount, style and duration of lithospheric thinning. These data may be used to determine the way in which the rheology of the lithosphere controls the details of the extension process. Many studies of lithospheric extension already exist and have reached, superficially at least, the same conclusion: i.e., that rheology plays a key role in controlling the rate, duration, magnitude and style of extension (see [1] for review). Depending on the observations being considered, however, a single property of the lithosphere's complex rheology is often highlighted while other aspects are assumed to be less important. At one extreme are models that emphasize the role of near-surface brittle deformation in extension; such models typically pre-define one or more fault surfaces, and proscribe the strain that they accommodate (e.g. [2-6]). At the other extreme are models that consider basin-wide patterns of thinning using a continuum approach. These models typically emphasize the role of deepseated ductile deformation, and largely ignore structural discontinuities within the basin (e.g., [7-10]).

More complex and holistic thermo-mechanical models for extension of the lithosphere have been developed as increased computational power has become available (e.g. [11-19]). The degree of complexity in current theoretical understanding of the process is evident from a review paper by Buck et al. [1], which quantifies and discusses the competing effects of at least six different factors that may control the style of extension that occurs. Many papers are able to explain generic features and gross variations in rift and/or passive margin geometry, such as overall width or degree of asymmetry (e.g., $[12,14,1,17,19])$. However, for specific rifts it is difficult to determine with certainty which factors may be more important than others and which ones may be ignored. 
Moreover, the increased complexity of more recent models for lithospheric extension has not been matched by an increased level of observational detail used to test these results.

Here we bring together, for the first time, a wide range of published observations of rift evolution during a $40 \mathrm{Myr}$ rift event and assess the extent to which existing models of lithospheric stretching can explain these observations. The basin studied is the Late Jurassic northern North Sea rift system (Fig. 1). For this area, a subsurface data set comprising 2D seismic reflection and refraction images, high-resolution 3D seismic surveys and biostratigraphically constrained well data has been used to document (a) temporal and spatial variability in the location and rate of strain accumulation during rifting as recorded by the fault population (e.g., [20,5,21-23]), and (b) the regional synrift strain rate variations derived from a $2 \mathrm{D}$ numerical inversion of tectonic subsidence patterns [24]. These data extend over the entire width of the basin $(\sim 200 \mathrm{~km})$ for an along-strike distance of $\sim 100 \mathrm{~km}$. To our knowledge, this study is the first to integrate such a wide variety of observational data, over different spatial and temporal scales, for an individual extensional province. We use these data to determine which mechanical properties of the lithosphere regulated strain accumulation through time across this basin.

\section{Multi-scale observations of Late Jurassic extension of the north- ern North Sea}

During the Mesozoic, the northern North Sea basin experienced two, approximately E-W oriented, phases of stretching: the Permo-Triassic and the Late Jurassic extensional episodes (e.g., [25-31]). We focus on the Late Jurassic extension event as this is particularly well documented. Extension during this episode began $\sim 170 \mathrm{Ma}$, in the Aalenian (mid-Jurassic), and finally ceased $\sim 130 \mathrm{Ma}$, in the Ryazanian (early Cretaceous). A central N-S trending low developed, the Viking Graben (VG), that is flanked in the west by the East Shetland Basin (ESB), and in the east by the Horda Platform (HP) (Fig. 2a). The width of the axial Viking Graben (sensu stricto) is $\sim 35-50 \mathrm{~km}$ whereas when the flanking platform areas are included the overall basin width is up to $\sim 250 \mathrm{~km}$ wide (Fig. 1 and 2). Maximum stretching during the Late Jurassic occurred at the rift axis $(\beta>1.3)$, i.e., within the VG itself, and lower amounts of extension occurred across the ESB and HP (see details below). The Late Jurassic extensional faults have accumulated up to several kilometers of throw and have steep to moderate dips, the angle of dip decreasing within the lower crust (Fig. 2b). Following the cessation of rifting in the early Cretaceous, the basin has largely undergone passive thermal subsidence with the development of classic "steer's head" basin geometry (Fig. 2b). 
Several recent studies have shown that for large areas of the northern North Sea basin many Late Jurassic faults cross-cut pre-existing Permo-Triassic structures (e.g., [32-34]). Moreover the variation in $\beta$-factors for the two rifting events are uncorrelated over most of the area [35]. It has also been shown that the thermal effects of Permo-Triassic rifting had dissipated prior to the onset of Late Jurassic extension [6]. Thus although pre-existing structure may have influenced Late Jurassic rift development the relationship is not one of straightforward inherited structural control.

There are essentially two types of data available for this area: (a) "highresolution" data, i.e., a dense grid of 3D reflection seismic and numerous cores, and (b) "low-resolution" data, i.e., regional 2D seismic reflection and refraction and gravity data. Thus, high-resolution observations in this area consist of interpreted 3D seismic combined with sedimentary facies analyses from cores to reconstruct depocentre evolution in 3D at sub-kilometer-scale resolution (e.g., $[21,22,36,37,23])$. The temporal control on these high-resolution studies is $\sim 2-3$ Myr, which allows patterns of displacement accumulation on individual faults to be resolved to a few 10s of meters. Interpretations of Late Jurassic basin formation for large areas of the ESB and HP now exist to this level of detail (e.g., Fig. $3 \& 4$ ). These high-resolution studies only relate to the structural evolution of, at most, the top $5-8 \mathrm{~km}$ of the crustal structure.

At a lower resolution, the regional seismic reflection, seismic refraction and gravity data reveal the deeper basin and upper mantle structure down to depths of 30-40 km. The image of overall crustal thinning across the entire rift, from Shetland to Norway, is thus available at a resolution of 10's km (Fig. 2b). These data can constrain the total amount of extension at the end of rifting. White [38] introduced a method for inverting basin subsidence curves to obtain the strain rate history during extension. Bellingham and White [24] extended the 1D method to 2D and presented the inversion result they obtained for this area of the northern North Sea. The spatial resolution of the Bellingham and White study [24] is $\approx 10 \mathrm{~km}$ and the temporal resolution is $10-20 \mathrm{Myr}$.

Compared to the 3D seismic and well core observations the strain rate inversion of Bellingham and White [24] is at least a factor of ten lower in both spatial and temporal resolution. However, it provides different and independent information because their inversion also uses data from the thermal subsidence (i.e., post-rift) phase of basin development. In other words the extension history they obtain is derived from the record of thermal perturbation and reequilibration on a lithospheric scale. Thus two obvious questions to ask are (1) what key characteristics of the extension history are revealed by the nearsurface ("high-resolution") versus whole lithosphere ("low-resolution") data sets? and (2) to what extent are these characteristics common to both data sets, i.e., do they agree or disagree? 


\section{Combined interpretation of the multi-scale data set}

\subsection{Extension history inferred from 2D strain rate inversion}

The strain rate inversion results of Bellingham and White [24] show three main results for this area. Firstly, throughout the whole rift event the maximum strain rate was lower over the flanking basin margin areas $\left(\sim 1 \times 10^{-16}\right.$ $\left.\mathrm{s}^{-1}\right)$ compared to the rift axis $\left(\sim 3 \times 10^{-16} \mathrm{~s}^{-1}\right)$. Although the difference in strain rate is less than an order of magnitude it is well resolved and, as we show below, it is significant for constraining the controlling mechanism(s). Secondly, extension ceased earlier on the basin margins ( $140 \mathrm{Ma})$ than it did at the rift axis $(\sim 130 \mathrm{Ma})$, although this is less well constrained by their inversion procedure. Thirdly, the distribution of total strain ( $\beta$-factor) is slightly asymmetric about the rift axis, i.e., on the $\operatorname{ESB} \beta \approx 1.3$, within the $\operatorname{VG} \beta \approx 1.5$, and across the HP $\beta \approx 1.15$. The smaller amounts of total extension recorded for the basin margins are therefore due to both shorter duration of extension and lower strain rates. Note that the strain rate inversion method gives systematically higher values of $\beta$ than previous workers had obtained for the shallow basin structure (e.g., [39]), possibly due to finite seismic resolution [40]. In this study we are not so interested in the absolute value of $\beta$ as in the lateral variation of $\beta$.

\subsection{Extension history inferred from 3D seismic and core interpretation}

The most detailed 3D observations are available for the ESB and thus we focus on this area below. However, we also summarise interpretations of "highresolution", largely 2D, observations for the HP [34]. Note that quoted fault throws have all been determined by measuring the offset of the pre-rift (i.e., pre-Late Jurassic) stratigraphy across each fault.

\subsubsection{Initiation of extension (170-155 Ma)}

The higher-resolution near-surface data sets place, first of all, a more precise constraint on the onset of extension, at least for the flanking basin margin areas (the earliest syn-rift at the rift axis is less well-resolved seismically). The first evidence for fault-controlled accommodation creation seen in the reflection data is $\sim 167 \mathrm{Ma}$ on the ESB [37]. On the HP extension initiated $\sim 170 \mathrm{Ma}[20]$. During the initial phase of extension, sediment supply outpaced the rate of tectonic subsidence so that a true measure of fault activity can be inferred from the coeval syn-rift stratigraphy [21]. Thus formation of early fault segments and their adjacent depocentres is clearly resolved (e.g., [21]). 
The first $\sim 10$ Myr of extension was associated with a broad zone of diffuse deformation, at least $200 \mathrm{~km}$ wide, i.e. extending from the western ESB across the VG to the western HP. The first Late Jurassic faults to initiate dipped both towards and away from the eventual rift axis and fault spacing was of the order of a few kilometers (e.g., Stage 1; Fig. 5a). Maximum fault throws of a few hundred meters at slip rates of $\leq 0.1 \mathrm{~mm} / \mathrm{yr}$ accrued during this period $[21,5]$. However, by $\sim 155 \mathrm{Ma}$, the faults that dipped towards the proto rift axis began to emerge as the dominant set controlling subsequent depocentre development on the ESB ([21]; Figs. 4b and 5b). Similary, strain localised at $\sim 160$ Ma onto the inward-dipping (i.e., westward-dipping) Brage fault, which is located approximately $25-30 \mathrm{~km}$ to the east of the VG on the HP [34]. At this time strain also localised onto the inward dipping fault that forms the eastern boundary of the VG. Activity on these inward-dipping faults resulted in the formation of half grabens comprised of fault blocks, 15-20 km wide, tilting away from the eventual rift axis. The basin also narrowed to $\sim 100 \mathrm{~km}$ wide by $\sim 155 \mathrm{Ma}$, with the Hutton-Murchison fault trend on the ESB defining the approximate western extent of active extension and the Brage fault on the HP defining the approximately the eastern extent.

\subsubsection{Evolution of extension (155-140 Ma)}

The present day pattern of faulting across the ESB clearly shows the dominant inward-dipping (i.e., eastward dipping) faults and the back-tilted half-graben between them (Fig. 3). Figure 3 also shows that the Visund-Gullfaks fault, which forms the western boundary to the VG, accumulated in excess of $5 \mathrm{~km}$ of throw during the Late Jurassic (e.g., [6]). The Brent-Statfjord fault, lying 20-30 km west of the axis has a maximum throw of only $2.7 \mathrm{~km}$ [21]. The Inner Snorre fault, at a similar position with respect to the rift axis as the Brent-Statfjord fault, has a comparable throw of $\sim 2.5 \mathrm{~km}$ (Fig. 3; [41]). The Murchison fault, which lies $40-50 \mathrm{~km}$ to the west of the axis has only $600 \mathrm{~m}$ maximum throw [23] and the Hutton fault on the same trend has $\sim 300 \mathrm{~m}$ of throw (Fig. 3; [42]). Faults located further west have even smaller maximum throws [43].

The decrease in maximum fault throw away from the rift axis on the ESB (Fig. 3) could be explained by either a shorter duration of fault activity or a slower rate of slip on faults located further away from the axis. Comparison of the Mcleod et al. [21] study of the Brent-Statfjord fault with our own study of the Murchison fault clearly shows that both of these faults initiated as similarly segmented structures at approximately the same time ( 167 Ma). However, when the geometry of the syn-rift fill is examined in detail the evolution of these two faults differs. Whereas the earliest part of the syn-rift stratigraphy ( $\sim 167 \mathrm{Ma}$ to $\sim 155 \mathrm{Ma}$ ) shows thickening into both faults, the younger syn-rift interval thins and onlaps towards the Murchison fault (Fig. 4a,b). Thus, while 
the Brent-Statfjord fault experienced an increased rate of slip (by a factor of $\sim \mathrm{x} 2$ ) later in the syn-rift (subsequent to $155 \mathrm{Ma}$; 21,22,44]; Fig. 4b), the Murchison fault appears to have experienced declining rates or cessation of activity during the same time interval (Fig. 5c,d).

There is also substantial evidence for migration of fault activity from the Inner Snorre fault to the Visund-Gullfaks fault. The Visund-Gullfaks fault experienced its maximum rate of slip between $\sim 148$ Ma and $\sim 140$ Ma $[22,45]$ whereas the Inner Snorre fault was most active between $\sim 155 \mathrm{Ma}$ and 148 Ma (Fig. 4c and 5d, [44]). The degree of thickening of the syn-rift wedge into the Inner Snorre fault decreases up-section, indicating that this fault is becoming less active during the latest synrift (Fig. 4c). Furthermore, the inset to Figure 4(c) shows erosional truncation of both syn- and pre-rift strata in the footwall crest of the Visund-Gullfaks fault. This pattern of erosion indicates that the rate of footwall uplift along the Visund-Gullfaks fault exceeded the rate of hangingwall subsidence along the Inner Snorre fault in the latest syn-rift ( 148-140 Ma). McLeod et al. [22] reconstructed the syn-rift paleogeography and sediment dispersal patterns to show that there was a progressive migration of fault activity from the Brent-Statfjord to the Inner Snorre fault and finally to the Visund-Gullfaks fault over a period of 15 Myr (Fig. 5).

In summary, the decrease in maximum fault throw away from the rift axis across the ESB results from the fact that both the duration and maximum slip rate decreased systematically from the rift axis (Fig. 5d). A similar pattern of fault growth is also observed on the HP. According to [34], the Brage fault on the HP was most active between $\sim 160 \mathrm{Ma}$ and $\sim 153 \mathrm{Ma}$, but it ceased to be active at $\sim 153 \mathrm{Ma}$ and has a maximum throw of only $\sim 700 \mathrm{~m}$. The fault that forms the eastern margin of the VG continued to be active for the remainder of the rift event [6].

\subsection{Conclusions of the combined interpretation}

The conclusions drawn from the near-surface versus whole lithosphere studies broadly agree. Both data sets indicate that, if the whole basin is considered, the duration of extension and the maximum strain rate (or maximum fault slip rate) are directly correlated. The greater resolution of the near surface data allows this correlation to be roughly quantified. For example, in areas that experienced $\leq 10-12$ Myr of extension (Murchison-Hutton trend and Brage fault) the maximum fault slip rates were typically $\sim 0.05 \mathrm{~mm} / \mathrm{yr}[21,5]$. Faults that were active for $\sim 20-25 \mathrm{Myr}$ (Brent-Statfjord and Inner Snorre faults) experienced maximum slip rates of $\sim 0.15-0.2 \mathrm{~mm} /$ yr [21]. The maximum fault slip rate on the Visund-Gullfaks fault, which was most likely active for the

entire rift event, i.e., $\sim 40 \mathrm{Myr}$, is estimated to be $0.3 \mathrm{~mm} / \mathrm{yr}$ (based on the 
age and maximum displacement of this fault).

The correlation between extension rate and duration also relates to the spatial evolution of the rift structure. For the first 10-15 Myr of extension ( 170-155 Ma) the zone of active faulting was $\sim 200 \mathrm{~km}$ wide with many low-slip rate faults active. During this interval faults dipping both towards and away from the eventual rift axis were accommodating strain (e.g., Fig. 5a). The available data can not rule out the possibility that there was some preferential strain accumulation within a proto- Viking Graben during this initial phase of distributed deformation. Subsequently (between $\sim 155 \mathrm{Ma}$ and $\sim 148 \mathrm{Ma}$ ), the zone of active faulting narrowed to $\sim 100 \mathrm{~km}$, with large areas of the HP and the western ESB becoming inactive (Fig. 5b). During this phase the faults that dipped towards the eventual rift axis became dominant and fault slip rates increased on these faults. At this stage the asymmetry of the rift also emerged, with the eastward dipping Visund-Gullfaks fault gradually becoming a more dominant structure (Fig. 2b). Between $~ 148-140$ Ma many of the inward dipping faults on the basin margins became inactive as strain accumulation localised within in a narrow zone, $<50 \mathrm{~km}$ wide, right at the axis. The final $10 \mathrm{Myr}$ of extension (140-130 Ma) was focussed entirely within the rift axis. During this final phase, crustal deformation may have been largely localised onto a single major shear zone, i.e., the Visund-Gullfaks fault, with the fault bounding the eastern margin of the VG representing a secondary antithetic structure.

\section{Comparison between the Late Jurassic strain accumulation pat- tern and existing models of lithospheric extension}

\subsection{To what extent does flexural rigidity play a role in controlling the rift evolution?}

The effective elastic thickness of the lithosphere $\left(T_{e}\right)$ is thought to be a key factor determining how large an extensional fault can grow and when it will cease to be active (e.g., [46,47,1]. We can compare the temporal evolution of faulting observed in this area with numerical models that explore the role of $\mathrm{T}_{e}$ in controlling how extensional faults grow (e.g., $\left.[48,49]\right)$. These models assume that flexural strength is concentrated in the brittle upper layer and they predict that new faults will initiate to take up further strain if/when flexural forces associated with existing faults become too great for continued motion to occur (Fig. 6a). The seismic reflection data, summarised here, clearly indicate that the number of active faults actually decreased through time and the width of the active rift zone narrowed as the extension progressed. In particular, the timing of movement on antithetic (outward-dipping) faults 
relative to the larger inward-dipping faults, as seen in this area, is not explained by the flexural model. (i.e., compare Fig. 6a with Fig. 4b). Moreover, the gradual emergence of the preferred inward dip-direction of the largest faults (and cessation of activity on outward dipping faults) can not be accounted for by this mechanism.

The overall narrowing of the basin through time might be attributed to lateral variations in $\mathrm{T}_{e}$, i.e., offset occurs preferentially on faults formed in low $\mathrm{T}_{e}$ areas. Note that the above models assume constant $\mathrm{T}_{e}$. The flexural force, $\Delta \mathrm{F}$, resisting motion on a normal fault with up to a few kilometers of displacement, as observed in this area, is given approximately by $\Delta F=\rho g \alpha w$, where $\rho$ is density, $g$ is acceleration due to gravity, and $w$ is fault offset. The flexural parameter $\alpha$ is related to $\mathrm{T}_{e}$ by $\alpha \propto \mathrm{T}_{e}^{3 / 4}$. Thus, according to these relationships, larger offset faults are likely to develop in areas where $T_{e}$ is lower. The increase in maximum fault throw towards the Viking Graben axis, documented above, implies a corresponding decrease in $\mathrm{T}_{e}$ from the basin margins towards the axis. Although $\mathrm{T}_{e}$ is expected to be lower in areas of greater lithospheric thinning and heating, i.e., at the rift axis, the $>\mathrm{x} 5$ variation in fault throw that we observe implies a significant variation in $T_{e}$. Such a large variation is inconsistent with the results of flexural back-stripping studies, which have successfully modeled this area assuming a constant, albeit low, value of $\mathrm{T}_{e}=1.5$ $\mathrm{km}$ [50]. Thus the fault pattern may be reflecting a lateral variation in $\mathrm{T}_{e}$, but the magnitude of the variation is unlikely to be as large as simple plate flexure theory predicts.

\subsection{To what extent does viscosity-controlled extension play a role in deter- mining the observed rift evolution?}

An alternative explanation for the pattern of strain accumulation and fault activity is that the viscous lower layers within the lithosphere are regulating the timing and magnitude of faulting. It has been shown that, if the lithosphere has a non-linear temperature-dependent rheology, then the total amount of stretching, the duration of stretching, and the maximum strain rate are all related [7,9,51,10]. Takeshita and Yamaji [51] and Newman and White [10] use a 1D model with a homogeneous non-linear viscous rheology and a constant force boundary condition to show how the extension history varies for different levels of applied force. For initial strain rates $>10^{-15} \mathrm{~s}^{-1}$ (high applied force) a thermomechanical instability occurs and rifting proceeds to full seafloor spreading. For initial strain rates $<10^{-15} \mathrm{~s}^{-1}$ (low applied force) finite extension occurs, i.e., a rift basin (or failed rift) is formed. For the latter case the total amount of stretching ( $\beta$-factor) and the maximum strain rate are correlated. Furthermore, the duration of stretching and the maximum strain rate are inversely related, i.e., areas that extend slowly continue to extend 
for longer periods of time. The cessation of extension in this model is due to the gradual replacement of weak crust by stronger mantle material as the lithosphere thins. Hence the same strengthening effect occurs after a longer time delay in lower strain rate areas. A constant force boundary condition is the most reasonable for modelling large-scale continental deformation when buoyancy forces are generated that are comparable to tectonic forces [52].

This model is the basis for what Newman and White refer to as "viscositycontrolled" extension. The apparent agreement between the near-surface seismic reflection observations and the strain inversion results suggests that a 1D model may indeed be appropriate for understanding the evolution of this basin. However, while the first of the model predictions is consistent with what is observed, the latter is not (Fig. 7). According to Newman and White [10], the predicted duration of extension across the low-strain-rate platform areas (ESB and HP) is approximately $60 \mathrm{Myr}$, whereas the observed duration is < 25-30 Myr in these areas (Fig. 7). The axis of the rift (the VG sensu stricto) experienced both the highest strain rate and the longest duration of extension (Fig. 7b).

The observations show that, for the first $\sim 30$ Myr of the rift history $(\sim 170$ $140 \mathrm{Ma}$ ), strain progressively localised at the rift axis (Fig. 5; Fig. 7b). In other words, the increasing rate at the axis was balanced by declining strain accumulation over the HP and the ESB during this interval of time. Thus constant strain rate could have been maintained overall, across the entire basin, even if a constant force was driving the deformation. During the final $10 \mathrm{Myr}$ of extension (140-130 Ma), once strain accumulation had localised within the VG, the strain rate declined from $\sim 3 \times 10^{-16} \mathrm{~s}^{-1}$ to $<10^{-17} \mathrm{~s}^{-1}$.

It is possible that the late-stage decline in strain rate and the ultimate cessation of rifting were externally controlled, i.e., there was a change in the plate driving forces. Alternatively, it can be explained by strengthening of the lithosphere, assuming the applied force remained constant as Newman and White [10] suggest. Crustal buoyancy forces are also likely to have contributed to the cessation of rifting [1]. For example, a $\beta$-factor of 1.2 produces a buoyancy force of $\sim 5 \times 10^{11} \mathrm{~N} / \mathrm{m}$ in $25-30 \mathrm{~km}$ thick crust, which is comparable (within an order or magnitude) to the force likely to be available for rifting (see [1] for discussion). However, the strain localisation behaviour of the first 25-30 Myr of extension can not be explained in terms of viscosity controlled extension because the strain rates in this basin $\left(<3 \times 10^{-16} \mathrm{~s}^{-1}\right)$ were consistently below the threshold needed for thermally induced strength loss to be significant. Other controls are therefore required to explain this phase. 
4.3 To what extent does fault interaction play a role in determining the observed rift evolution?

Many of the observations of fault evolution in the ESB during the first 25-30 Myr of the extension history may be explained in terms of fault interaction. For example, the simultaneous increase in displacement rate on the inward dipping faults and cessation of activity on the outward dipping faults, as seen in Figure $4 \mathrm{~b}$ is easily explained by this process (Fig. 6b). Intersection of two faults with opposing dips causes one fault to become inactive and the strain to be taken up by the remaining active fault [53,54]. A fault may also become inactive if it lies in the stress shadow of a neighboring, more active, fault even if the two faults do not intersect [55]. A typical feature of numerical models in which growing faults interact through time is the development of a wide range of fault sizes, similar to that seen in the northern North Sea area (e.g., $[55])$.

Hardacre and Cowie [56] modelled the spontaneous nucleation and growth of dipping extensional faults in a $2 \mathrm{D}$ cross-section. These authors show that when a lateral strain gradient is imposed as an initial condition across the model, faults that dip toward the region of highest strain emerge as the dominant fault set, while those that dip away cease to be active. Ishikawa and Otsuki [57] also found a correlation between the magnitude of the lateral strain gradient and a dominant fault dip-direction. Thus, if a strain gradient existed from the basin margin towards the rift axis, we can explain both the observed emergence of the major inward dipping faults and the highest rates of slip on the faults proximal to the axis.

There are two key observations that suggest that the strain gradient became gradually more pronounced through time. First of all, on the ESB, at least, outward facing faults initiated early on and only became inactive after about 11-12 Myr of extension. This would suggest that early in the extensional history there was not a well-developed strain gradient. Second, we observe a gradual but significant narrowing of the zone of active faulting (from $\sim 200 \mathrm{~km}$ to $<50 \mathrm{~km}$ ) over the $40 \mathrm{Myr}$ of rifting. The strain gradient will of course increase if the mechanical thickness variation from the basin margins to the axis increases. As the thickness of the lithosphere is thermally controlled, a higher geothermal gradient at the axis will reduce the mechanical thickness and thus enhance the strain in that area relative to the margins. 
In order investigate the effect of thermal structure on faulting we model the deformation using the 2-D finite-element approach of Behn et al. [17], which is decribed in detail in the Appendix. Figures 8 and 9 show the results of using this model to reproduce the pattern of faulting seen in the northern North Sea. We used published values of strain rates, layer thicknesses and thermal structure for the late Jurassic rift event in this area (e.g., [6,10], see Fig. 8 caption). The three panels shown in Figure 8 represent separate model runs with independent starting conditions designed to illustrate the 3 sequential stages of rift evolution shown in Figure 5. Although this approach does not explicitly calculate the advection and diffusion of heat associated with finite duration extension, it provides a first order prediction of the style of deformation that will develop for a given thermal regime.

In Figure 8, the top panel corresponds to Stage 1 of Figure 5 and shows that when a weak lateral temperature gradient is imposed, deformation is distributed between sets of conjugate normal faults with similar strain rates. Active faulting extends to distances of up to $\sim 75 \mathrm{~km}$ either side of the rift axis. The lower two panels of Figure 8 correspond to Stages 2 and 3 of Figure 5. As the lateral temperature gradient becomes more pronounced, active faults dip preferentially towards the area where the geothermal gradient is highest (half-graben development of Stage 2; Fig. 5) and the highest strain rates occur where the lithosphere is thinnest. The total width of the zone of active faulting narrows from $\sim 150 \mathrm{~km}$ to $\sim 50 \mathrm{~km}$ (Stage 3) (Figs. $8 \& 9$ ). We found that the depth extent and horizontal pattern of faulting were very sensitive to the imposed thermal structure and horizontal strain rate. The relatively cool geotherm assumed for this area in the Late Jurassic $\left(12-18^{\circ} \mathrm{C} / \mathrm{km}\right)$ could cause brittle faulting to penetrate to greater depth. However, the very low strain rate $\left(10^{-16} \mathrm{~s}^{-1}\right)$ offsets the effect of a cool thermal structure because it allows the lower crust and upper mantle to deform by flow to higher levels of stress (e.g., $[1])$.

The model developed by Behn et al. [17] is also able to account for the fact that the overall width of the basin narrows from $\sim 250 \mathrm{~km}$ in west-east width at a latitude of $61^{\circ} \mathrm{N}$, to $\sim 75 \mathrm{~km}$ in west-east width further south $\left(59^{\circ} \mathrm{N}\right.$; Figs. 1). A narrower rift is formed if there is either thicker crust or a higher axial geothermal gradient compared to the basin margins, but the along-strike variation in either of these quantities need not necessarily be large. At low geothermal gradients of $\leq 25^{\circ} \mathrm{C} / \mathrm{km}$ the width is very sensitive to relatively small changes in either of these parameters.

The predicted fault pattern (Figs. 8 and 9) is much simpler than the observed pattern. This is due to the fact that there is no heterogeneity in yield 
strength included in this model. Models in which random heterogeneity is included produce a wide range of fault sizes and the periodic spacing of the faults disappears [56]. Pre-existing structures will contribute to a strongly heterogeneous crustal strength distribution. Much of the detailed (i.e. km-scale) rift geometry, e.g., complex fault patterns and along-strike variations in rift asymmetry, may be due to this heterogeneity.

\section{Discussion and Conclusions}

Based on the combined data interpretation a number of key observations have been made: (1) a wide range of fault sizes formed during the extensional episode; (2) present-day maximum fault throw increases towards rift axis; (3) a preferred inward dip direction of large faults emerged as extension progressed and was accompanied by cessation of activity on outward dipping smallerscale faults; (4) maximum fault slip rate (or maximum strain rate) correlates with fault displacement (or stretching factor, $\beta$ ) as well as with the duration of extension; and finally, (6) the zone of active extension narrowed through time (from $\sim 200 \mathrm{~km}$ to $<50 \mathrm{~km}$ over $40 \mathrm{Myr}$ ). Such systematic spatio-temporal relationships would not be predicted if Late Jurassic extension was entirely controlled by the pre-existing (i.e., Permo-Triassic) structure of this area. We have therefore evaluated these observations in the light of existing theory of lithospheric deformation and reached the following conclusions.

1) The lack of a characteristic fault size and the systematic increase in fault throw and length towards the rift axis implies that the value of $T_{e}$ varies significantly $(>\mathrm{x} 5)$ across the basin. There is no independent evidence for a large lateral variation in $T_{e}$; previous workers have successfully modelled the basin stratigraphy assuming a constant value. Thus, although the fault pattern may be reflecting a lateral variation in $T_{e}$, the magnitude of the variation is probably much smaller than simple plate flexure theory would predict. In any case, existing plate flexure models for fault evolution assume a constant $T_{e}$ and they are unable to explain the migration of fault activity through time seen in this area.

2) The gradual emergence of the dominant inward-dipping fault set, the higher slip rates on the faults closest to the rift axis and cessation of fault activity away from the axis, are all consistent with fault growth in the presence of a regional strain gradient. We infer that this pattern of deformation is a response to an evolving thermal structure in the thinning lithosphere. The mechanical lithosphere is thinner (and $T_{e}$ lower) where the geothermal gradient is higher, i.e., at the rift axis. Faults develop with a preferential dip-direction, and slip-rates increasing, towards the region of highest geothermal gradient. Detailed field observations of modern rifts have documented a similar pattern 
of "migrating" fault activity through time, e.g., the Gulf of Corinth [58] and the Gulf of Suez [59]. In each case the migration sense is towards the locus of maximum extension.

3) The observed patterns of strain rate, strain $(\beta)$ and rift duration indicate that the first 25-30 Myr of extension in this area (170-140 Ma) was dominated by strain localisation. The strain rate at the rift axis gradually increased during this time interval while strain rates across the basin margins declined. During the final phase of basin development (140-130 Ma) strain accumulation was focused within the rift axis but the strain rate declined rapidly from $\sim 3 \times 10^{-16} \mathrm{~s}^{-1}$ to $<10^{-17} \mathrm{~s}^{-1}$. Strain localisation implies a strain-softening effect within the lithosphere, while the eventual cessation of rifting implies that strain hardening became more important through time (assuming no change in external forces may be invoked). Existing models for "viscosity-controlled" extension (e.g., [10]) are unable to explain this dual behaviour because, at strain rates of the order of $10^{-16} \mathrm{~s}^{-1}$, thermally induced strength loss is insignificant.

4) The model presented in Section 4.3.1 illustrates an alternative mechanism for the strain localisation, which depends on a coupling between brittle fault growth and temperature dependent viscous deformation. A relatively small perturbation to the thermal structure of the lithosphere is shown to exert an important control on fault development and strain localisation within the brittle layer, very similar to what is observed (see (2)). We argue that, due to strain (and/or strain rate) softening along these faults, a feedback will develop between the evolving thermal structure and the growing faults. In other words, extension on faults further focusses lithospheric thinning and heating, resulting in localisation on a lithospheric scale even at low strain rates. Our observations suggest that this process takes several tens of millions of years and results in the bulk of the total extension occurring within an axial zone only $35-50 \mathrm{~km}$ wide within a basin that is $200-250 \mathrm{~km}$ wide overall. As the strain localises, the loss of heat will increase due to increased lateral heat diffusion. Furthermore, replacement of weak crust by stronger mantle material will become progressively more important during the latter phases of the extension history when crustal buoyancy effects are also larger. Thus the coupled mechanism that we propose can explain why the deformation is initially strongly localising but also, ultimately, self-limiting without having to invoke a change in external boundary conditions.

5) Following from (3) and (4), the method proposed by Newman and White [10] for deriving the parameters of power-law creep within the lithospheric mantle from the subsidence history of wells is not applicable to wells located on the basin margins (e.g., ESB and HP). The only wells that may actually record deep-seated viscous strain rate variations are those that penetrate the synrift section at the rift axis and thus record the entire extension history. Such wells are extremely rare. 
6) The observation of progressive strain localization is not unique to the northern North Sea, but can be observed in many modern rifts. For example, in East Africa, the $<15 \mathrm{~km}$ wide zone of active rifting in the north is more mature than the $65 \mathrm{~km}$ wide rift system to the south [60]. Gupta and Scholz [61] interpret this to mean distributed strain occurring in the southern part of the rift, whereas strain has localized at the rift axis in the north. Another example is the Gulf of Suez which has evolved through time, from a zone $\sim 100 \mathrm{~km}$ wide when it first formed ( $\sim 20 \mathrm{Ma}$; mid-Miocene) to a zone only $\sim 50 \mathrm{~km}$ wide during the Pliocene [62]. Thus we believe that the conclusions of this study are likely to be generally applicable.

\section{Acknowledgements}

This collaboration initiated while PAC was a Visiting Guest Investigator at WHOI. The idea emerged from discussions with A. McLeod. PAC was partially supported by a University Research Fellowship from the Royal Society of London and travel funds from WHOI. Useful discussions with J. Maclennan, N. White, R. Buck, J. Hopper, R. Huismans significantly improved this manuscript. Comments by L. Geoffroy and an anonymous reviewer helped clarify several aspects of the text. WHOI contribution number 11207. 
Fig. 1. (a) The North Sea rift system. Location of Figure 2(a) shown by dashed box. Grey shading indicates thickness of Upper Jurassic sediment accumulation and reflects complexity of accommodation creation across the basin.

Fig. 2. (a) Map of north Viking Graben with same shading as Fig. 1. Dashed boxes show locations of Figure 3(a) and detailed study of Horda Platform by ter Voorde et al. [5]. (b) Line drawing interpretation of deep-seismic profile NSDP84-1 oriented NW-SE across the northern North Sea basin (Modified from [63]). For location of line see Fig. 2(a).

Fig. 3. Structural map of the East Shetland Basin, area located in Fig. 2(a). Colors represent depth to top syn-rift (base Cretaceous reflector): blue-purples are deep, and red-yellows are shallow. This surface represents the basin bathymetry at the end of Late Jurassic extension. Image is illuminated from the NW; easterly-dipping faults are shown in shadow. Numbers refer to the seismic sections shown in Figure 4.

Fig. 4. Seismic reflection profiles and interpretations across (a) Murchison fault (line 1), (b) Brent-Statfjord fault (line 2; modified from [21]), and (c) Snorre-Visund faults (line 3) (see Fig 3 for location of profiles and text for explanation).

Fig. 5. Cartoon illustration of the migration in fault activity through time across the ESB. In Stage 1 (Fig. 5a) both inward and outward facing faults develop with similar slip rates. In Stage 2 (after 11-12 Myr; Fig. 5b) the outward dipping faults become inactive and the inward dipping faults develop higher slip rates. Dashed arrows indicate strain localising onto inward dipping faults in Stage 2. In Stage 3 (Fig. 5c) the highest rates of fault slip occur on the Gullfaks-Visund fault and faults further off-axis switch off (direction of strain localisation indicated by dashed arrows). The graph in Fig. 5d summarises fault throw versus time for the three main fault systems.

Fig. 6. Comparing the different fault migration patterns predicted by (a) plate flexure, versus (b) fault interaction. Numbers indicate order of fault evolution. In (a), the initiation of secondary fault 2 is caused by plate bending adjacent to high-angle fault 1. Ultimately the cessation of movement on fault 1 forces another fault to form (fault 3) most likely in the footwall [49]. In (b) a number of faults initiate simultaneously (all faults labeled 1). Due to fault interaction one fault emerges as the dominant structure (fault 1,2,3) and faults in the foot-wall and hanging-wall areas become inactive as extension progresses. Grey shading indicates sediment packages associated with different time periods of fault movement

Fig. 7. Comparison between (a) the prediction of 1D "viscosity-controlled" extension [10], and (b) observations based on the combined interpretation (see Section 3). Note that part (b) is derived from estimates of rates and durations based on data available and is partly schematic. 
Fig. 8. Simulating the 3 Stages of fault evolution (Fig. 5) using the model of Behn et al. [17]. Each panel shows the instantaneous strain rate (right half of diagram) and viscosity structure (left hand side of diagram) calculated for a given set of thermal and rheological input parameters. Strain rates are shown relative to a reference strain rate of $10^{-16} \mathrm{~s}^{-1}$. Viscosities shown in grey shade indicate brittle failure, whiter shades indicate lower effective viscosities. Thick white line $=700^{\circ} \mathrm{C}$ isotherm, $\mathrm{C}=$ crust, $\mathrm{M}=$ mantle. The panels approximate the gross late Jurassic extension history and each one represents a separate model run; the evolution is not modelled explicitly. From top to bottom, the crustal thickness decreases from $35 \mathrm{~km}$ to $15 \mathrm{~km}$ while there is a corresponding increase in the geothermal gradient at the rift axis from $12^{\circ} \mathrm{C} / \mathrm{km}$ to $18^{\circ} \mathrm{C} / \mathrm{km}$. Increase in crustal thickness towards rift margins does not significantly influence result and is ignored. Estimates of extensional strain rate, thermal structure, crustal thickness and lithospheric rheology specific to this area for the late Jurassic are taken from [6,24]. The following flow law paremeters were used for all the experiments (Eqn. A1): Upper crust $(Q=172.6 \mathrm{~kJ} / \mathrm{mol}, A=3.165$ x $\left.10^{-2} \mathrm{MPa}^{-n} \mathrm{~s}^{-1}, n=1.9\right)$; Lower crust $\left(Q=212 \mathrm{~kJ} / \mathrm{mol}, A=3.165 \times 10^{-2}\right.$ $\left.\mathrm{MPa}^{-n} \mathrm{~s}^{-1}, n=2.4\right) ;$ Mantle $\left(Q=510 \mathrm{~kJ} / \mathrm{mol}, A=7 \times 10^{4} \mathrm{MPa}^{-n} \mathrm{~s}^{-1}, n=3\right)$. A cosine-bell function is used to define the isotherm geometry.

Fig. 9. (a) Surface topography and (b) surface strain rate extracted for the 3 simulations shown in Figure 8. 


\section{A Finite Element Model}

The results shown in Figure 8 and described in Section 4.4 were obtained using a 2-D visco-pseudoplastic finite-element model [13,17]. A strain-rate dependent rheology is assumed for the brittle layer to simulate the rate-dependence of frictional strength observed in laboratory studies, e.g., [64,65]. For viscous flow we assume a non-Newtonian temperature-dependent rheology [66,67]:

$$
\dot{\varepsilon}=A\left(\sigma_{1}-\sigma_{3}\right)^{n} \exp (-Q / n R T)
$$

where $\dot{\varepsilon}$ is the uniaxial strain rate, $\sigma_{1}$ and $\sigma_{3}$ are the maximum and minimum principle stresses, $n$ is the power law exponent, $Q$ is the molar activation energy, $A$ is a material strength constant, $T$ is the temperature, and $R$ is the gas constant. Although the relationship between stress and strain rate is nonlinear, we can define a linearized viscosity law, e.g., $[68,69]$, by

$$
\tau_{i j}=\sqrt{2} \eta \dot{\varepsilon}_{i j}
$$

where $\tau_{i j}$ is the stress tensor, $\eta$ is the effective viscosity, and $\dot{\varepsilon}_{i j}$ is the strainrate tensor. This linearization leads to an expression for the apparent effective Newtonian viscosity

$$
\eta=B \dot{\varepsilon}_{I I}^{(1-n) / n} \exp (Q / n R T)
$$

where $\dot{\varepsilon}_{I I}$ is the second invariant of the stain rate tensor, and $B$ is a material constant related to $A$ by $B=0.25(1.33 / A)^{1 / n}[68]$.

In the brittle regime, strength is assumed to be controlled by a frictional resistance law, e.g., [70,71]:

$$
\tau_{\max }=C_{0}-\mu \sigma_{n}
$$

where $C_{0}$ is the cohesive strength, $\mu$ is the coefficient of friction, and $\sigma_{n}$ is approximately equal to the lithostatic stress. The rate dependence of frictional strength is simulated by defining an apparent friction coefficient, $\mu^{\prime}$, as

$$
\mu^{\prime}=\mu_{0}\left[1-\gamma \log _{10}\left(\dot{\varepsilon}_{I I} / \dot{\varepsilon}_{0}\right)\right]
$$

where $\mu_{0}$ is the reference coefficient of friction, $\gamma$ is the strain-rate softening coefficient, and $\dot{\varepsilon}_{0}$ is the reference strain-rate. This formulation not only simulates strain-rate weakening for $\dot{\varepsilon}_{I I}>\dot{\varepsilon}_{0}$, but also generates strengthening in regions where $\dot{\varepsilon}_{I I}<\dot{\varepsilon}_{0}$. Behn et al. [17] showed that $\gamma \geq 0.10$ results in 
efficient strain localization in models of lithospheric deformation for plausible rheological structures, and we choose $\gamma=0.15$ for the numerical experiments presented in this study. Acknowledging that this approach neglects many of the complexities of the earthquake process, we interpret these regions of high strain-rate to be analogous to fault zones. Note that in the visco-pseudoplastic formulation implemented here, the pattern of deformation is found to be relatively insensitive to the values of $\mu_{0}$ and $C_{0}$.

Following the procedures described in [13] and [17] we calculate deformation in two 2-D vertical sections of lithosphere. At each time-step the element viscosities are calculated from the temperature and evolving strain-rate fields. If the resulting maximum principle shear stress calculated from Equation A2 is greater than the frictional failure criterion, $\tau_{\max }$, the effective viscosity of the element is reset to $\eta=\tau_{\max } / \sqrt{2} \dot{\varepsilon}_{I I}$. The initial element viscosities are calculated assuming a uniform background strain-rate of $10^{-16} \mathrm{~s}^{-1}$.

We note that the numerical experiments presented here should be treated only as a proxy for the initial pattern of faulting that develops for a given set of thermal conditions, rather than as a method to study the evolution of individual faults over geologic time. The rotation of fault blocks in highly extended terrains generates large flexural stresses, e.g., [46,47], that are not accounted for in our visco-pseudoplastic formulation. By limiting our calculations to $1 \%$ total strain, we can safely ignore these elastic stresses and eliminate numerical inaccuracies associated with the distortion of model elements. Furthermore, because we are considering only the initial pattern of faulting associated with a given set of thermal conditions we do not solve for the evolution of temperature

The model setup and boundary conditions are illustrated in Fig. A1. Deformation is driven by applying a uniform horizontal velocity of $1 \mathrm{~km} / \mathrm{Myr}$ to the right-hand side of the model space $x=X_{0}$, giving an initial reference strainrate of $10^{-16} \mathrm{~s}^{-1}$. For numerical efficiency, a symmetry condition is imposed on the left-hand side of model $(x=0)$ by setting the horizontal velocity, $u_{x}$, and the shear stress, $\tau_{x z}$, equal to zero. The model dimensions $\left(X_{0}=300 \mathrm{~km}\right.$ and $Z_{0}=120 \mathrm{~km}$ ) are specified to ensure that the boundaries do not influence the final solution and the finite element grid is adjusted to give maximum resolution (grid size of $1 \mathrm{~km} \mathrm{x} 1 \mathrm{~km}$ ) near the rift axis. The thermal gradients and crustal thickness values used for each of the stages of fault evolution, as well as material properties assumed for the crust and mantle, are given in the caption to Fig. 8. 
Fig. A.1. Model setup for mechanical model of lithospheric stretching. The model space is symmetric about the rift axis, with dimensions $X_{0}=300 \mathrm{~km}$ and $Z_{0}=120$ $\mathrm{km}$. A uniform horizontal velocity $U=1 \mathrm{~km} / \mathrm{Myr}$ is applied to the right-hand side of the model space, and extension is continued until 1\% total strain is achieved. Crustal thickness, $t_{c}$, is constant across-axis but differs for each stages of fault evolution. 


\section{References}

[1] W. R. Buck, L. L. Lavier, A. Poliakov, How to make a rift wide, Phil. Trans. R. Soc. Lond. 357 (1999) 671-693.

[2] G. C. P. King, R. S. Stein, J. B. Rundle, The growth of geological structures by repeated earthquakes: 1. conceptual framework, J. Geophys. Res. 93 (1988) $13307-13318$.

[3] J. K. Weissel, G. Karner, Flexural uplift of rift flanks due to tectonic denudation of the lithosphere during extension, J. Geophys. Res. 94 (1989) 13919-13950.

[4] N. J. Kusznir, G. Marsden, S. S. Egan, A flexural-cantilever simple-shear/pureshear model of continental lithosphere extension: Applications to the Jeanne dA'rc Basin, Grand Banks and Viking Graben, North Sea, in: A. M. Roberts, G. Yielding, B. Freeman (Eds.), The Geometry of Normal Faults, no. 56 in Geol. Soc. Spec. Pub., 1991, pp. 41-60.

[5] M. T. Voorde, R. Ravnås, R. Færseth, S. Cloetingh, Tectonic modelling of the Middle Jurassic synrift stratigraphy in the Oseberg-Brage area, northern Viking Graben, Basin Res. 9 (1997) 133-150.

[6] M. T. Voorde, R. Færseth, R. H. Gabrielsen, S. Cloetingh, Repeated lithosphere extension in the northern Viking Graben: a coupled or a decoupled rheology?, in: A. Nøttvedt (Ed.), Dynamics of the Norwegian margin, no. 167 in Spec. Publ. Geol. Soc., Lond., 2000, pp. 59-81.

[7] P. C. England, Constraints on extension of continental lithosphere, J. Geophys. Res. 88 (1983) 1145-1152.

[8] M. T. Zuber, E. M. Parmentier, Lithospheric necking: a dynamic model for rift morphology, Earth and Planetary Science Letters. 77 (1986) 373-383.

[9] L. J. Sonder, P. C. England, Effects of a temperature-dependent rheology on large-scale continental extension, J. Geophys. Res. 94 (1989) 7603-7619.

[10] R. Newman, N. White, The dynamics of extensional sedimentary basins: constraints from subsidence inversion, Phil. Trans. Royal Soc. London 357 (1999) 805-830.

[11] J. Braun, C. Beaumont, Styles of continental rifting: results from dynamic models of lithospheric extension, in: C. Beaumont, A. J. Tankard (Eds.), Sedimentary Basins and Basin Forming Mechanisms, no. 12 in Can. Soc. Petrol. Geol. Mem., 1987, pp. 241-258.

[12] G. Bassi, Relative importance of strain rate and rheology for the mode of continental extension, Geophys. J. Int. 122 (1995) 195-210.

[13] G. Neumann, M. Zuber, A continuum approach to the development of normal faults, in: J. Daemen, R. Schultz (Eds.), 35th US Symposium on Rock Mechanics, Balkema, Lake Tahoe, Nevada, 1995, pp. 191-198. 
[14] J. R. Hopper, W. R. Buck, The effect of lower crustal flow on continental extension and passive margin formation, J. Geophys. Res. 101 (1996) 2017520194.

[15] E. Burov, A. Poliakov, Erosion and rheology controls on synrift and postrift evolution: Verifying old and new ideas using a fully coupled numerical model, J. Geophys. Res. 106 (2001) 16461-16481.

[16] L. L. Lavier, W. R. Buck, A. N. B. Poliakov, Factors controlling normal fault offset in an ideal brittle layer, J. Geophys. Res. 105 (2000) 23431-23441.

[17] M. D. Behn, J. Lin, M. T. Zuber, A continuum mechanics model for normal faulting using a strain-rate softening rheology: Implications for thermal and rheological controls on continental and oceanic rifting, Earth Planet. Sci. Lett. 202 (2002) 202.

[18] M. D. Behn, J. Lin, M. T. Zuber, Effects of hydrothermal cooling and magma injection on mid-ocean ridge temperature structure, deformation and axial morphology, in: C. German, J. Lin, L. Parsons (Eds.), Thermal Regime of Ocean Ridges and Dynamics of Hydrothermal Circulation, Geophysics Monograph, American Geophysical Union, 2004, p. (in press).

[19] R. S. Huismans, C. Beaumont, Symmetric and asymmetric lithospheric extension: Relative effects of frictional-plastic and viscous strain softening, J. Geophys. Res. 108 (2003) doi:10.1029/2002JB002026.

[20] R. Ravnås, K. Bondevik, W. Helland-Hansen, L. Lømo, A. Ryseth, R. J. Steel, Sedimentation history as an indicator of rift initiation and development: the Late Bajocian - Bathonian evolution of the Oseberg-Brage area, northern North Sea, Norsk Geol. Tiddsk. 77 (1997) 205-232.

[21] A. E. Mcleod, N. H. Dawers, J. R. Underhill, The propagation and linkage of normal faults: Insights from the Strathspey-Brent-Statfjord fault array, northern North Sea, Basin Res. 12 (2000) 263-284.

[22] A. E. Mcleod, J. R. Underhill, S. J. Davies, N. H. Dawers, The influence of fault array evolution on syn-rift sedimentation patterns: Controls on deposition in the Strathspey-Brent-Statfjord half-graben, northern North Sea, Bull. Am. Assoc. Petrol. Geol. 86 (2002) 1061-1093.

[23] M. J. Young, R. L. Gawthorpe, S. Hardy, Growth and linkage of a segmented normal fault zone; the Late Jurassic Murchison-Stratfjord North fault, northern North Sea, J. Struct. Geol. 23 (2001) 1933-1952.

[24] P. Bellingham, N. White, A general inverse method for modeling extensional sedimentary basins, Basin Res. 12 (2000) 219-226.

[25] G. Enyon, Basin development and sedimentation in the Middle Jurassic of the northern North Sea, in: L. V. Illing, G. D. Hobson (Eds.), Petroleum Geology of the Continental Shelf of Northwest Europe, London, Heyden and Son, 1981, pp. 196-204. 
[26] M. E. Badley, T. Egeberg, O. Nipen, Development of rift basins illustrated by the structural evolution of the Oseberg structure, block 30/6, offshore Norway, J. Geol. Soc., Lond. 141 (1984) 639-649.

[27] M. E. Badley, J. D. Price, C. R. Dahl, T. Agdestein, The structural evolution of the North Viking Graben and its bearing upon extensional modes of basin formation, J. Geol. Soc., Lond. 145 (1988) 455-472.

[28] K. S. Lervik, A. M. Spencer, G. Warrington, Outline of the Triassic stratigraphy and structure in the central and northern North Sea, in: J. Collinson (Ed.), Correlation in hydrocarbon exploration, Graham and Trotman, London, 1989, pp. $173-190$.

[29] A. M. Roberts, G. Yielding, M. E. Badley, A kinematic model for the orthogonal opening of the late jurassic North Sea rift system, Denmark - mid Norway, in: D. J. Blundell, A. D. Gibbs (Eds.), Tectonic evolution of the North Sea rifts, Clarendon Press, Oxford, 1990, pp. 180-199.

[30] R. J. Steel, A. Ryseth, The Triassic - Early Jurassic succession in the northern North Sea: Megasequence stratigraphy and intra-Triassic tectonics, in: R. F. P. Hardman, J. Brooks (Eds.), Tectonic events responsible for Britains Oil and Gas Reserves, no. 55 in Spec. Publ. Geol. Soc., Lond., 1990, pp. 139-168.

[31] G. Yielding, M. E. Badley, A. M. Roberts, The structural evolution of the Brent Province, in: A. C. Morton, R. S. Haszeldine, M. R. Giles, S. Brown (Eds.), Geology of the Brent Group, no. 61 in Spec. Publ. Geol. Soc., Lond., 1992, pp. 27-43.

[32] M. Tomasso, J. R. Underhill, R. A. Hodgkinson, M. J. Young, Structural styles and depositional architecture in the Triassic of the Ninian and Alwyn North fields: Implications for basin development and prospectivity in the northern $\mathrm{rn}$ North Sea, in press, Marine and Petroleum Geology.

[33] R. B. Færseth, Interaction of Permo-Triassic and Jurassic extensional fault blocks during the development of the northern North Sea, J. Geol. Soc., Lond. 153 (1996) 931-944.

[34] R. B. Færseth, R. Ravnås, Evolution of the Oseberg fault-block in the context of the northern North Sea structural framework, Mar. Petrol. Geol. 15 (1998) $467-490$.

[35] T. Odinsen, P. Christiansson, R. H. Gabrielsen, J. I. Faleide, A. M. Berge, The geometries and deep structure of the northern North Sea rift system, in: A. Nøttvedt (Ed.), Dynamics of the Norwegian margin, no. 167 in Spec. Publ. Geol. Soc., Lond., 2000, pp. 41-57.

[36] N. H. Dawers, J. R. Underhill, The role of fault interaction and linkage in controlling syn-rift stratigraphic sequences: Late Jurassic, Statfjord East area, northern North Sea, Bull. Am. Assoc. Petrol. Geol. 84 (2000) 45-64.

[37] S. J. Davies, N. H. Dawers, A. E. Mcleod, J. R. Underhill, The structural and sedimentological evolution of early synrift sucessions: the Middle Jurassic Tarbert Formation, North Sea, Basin Res. 12 (2000) 343-366. 
[38] N. White, An inverse method for determining lithospheric strain rate variation on geological timescales, Earth and Planetary Science Letters. 122 (1994) 351371.

[39] A. M. Roberts, G. Yielding, N. Kusznir, I. M. Walker, D. Dorn-Lopez, Mesozoic extension in the North Sea: Constraints from flexural backstripping, forward modelling and fault populations, in: J. R. Parker (Ed.), Petroleum Geology of Northwest Europe: Proceedings of the 4th Conference, The Geological Society, London, 1993, pp. 1123-1136.

[40] R. A. Marrett, R. W. Allmendinger, Amount of extension on "small" faults: An example from the Viking Graben, Geology 20 (1992) 47-50.

[41] H. Fossen, T. Odinsen, R. B. Færseth, R. H. Gabrielsen, Detachment and low-angle faults in the nothern North Sea rift system, in: A. Nøttvedt (Ed.), Dynamics of the Norwegian margin, no. 167 in Spec. Publ. Geol. Soc., Lond., 2000, pp. 105-131.

[42] D. B. Haig, The Hutton Field, Blocks 211/28, 211/27, UK North Sea, in: I. L. Abbotts (Ed.), United Kingdom Oil and Gas Fields, 25 Years Commemorative Volume, no. 14 in Geological Society Memoir, 1991, pp. 135-143.

[43] C. E. Gill, The role of antithetic faulting in setting up the Hudson Play, East Shetland Basin, UK Northern North Sea, AAPG Annual ConventionAbstract A62.

[44] A. M. Roberts, G. Yielding, M. E. Badley, Tectonic and bathymetric controls on stratigraphic sequences within evolving half-graben, in: G. D. Williams, A. Dobb (Eds.), Tectonics and Seismic Sequence Stratigraphy, no. 71 in Spec. Publ. Geol. Soc., Lond., 1993, pp. 87-121.

[45] R. B. Færseth, T. S. Sjøblom, R. J. Steel, T. Liljedahl, B. E. Sauar, Tectonic controls on Bathonian-Volgian synrift successions on the Visund fault block, northern North Sea, in: R. J. Steel, V. L. Felt, E. P. Johannessen, C. Mathieu (Eds.), Sequence Stratigraphy on the Northwest European Margin, no. 5 in Norwegian Petroleum Society, Special Publication, 1995, pp. 325-346.

[46] D. W. Forsyth, Finite extension and low-angle normal faulting, Geology 20 (1992) 27-30.

[47] W. R. Buck, Effects of lithospheric thickness on the formation of high- and low-angle normal faults, Geology 21 (1993) 933-936.

[48] L. L. Lavier, W. R. Buck, Half graben versus large-offset low-angle normal fault: Importance of keeping cool during normal faulting, J. Geophys. Res. 107 (2002) 10.1029/2001JB000513.

[49] R. Hassani, J. Chéry, Anelasticity explains topography associated with basin and range normal faulting, Geology 24 (1996) 1095-1098.

[50] A. M. Roberts, N. J. Kusznir, G. Yielding, P. Styles, 2D flexural backstripping of extensional basins: The need for a sideways glance, Petroleum Geoscience 4 (1998) 327-338. 
[51] T. Takeshita, A. Tamaji, Acceleration of continental rifting due to thermomechanical instability, Tectonophysics 181 (1990) 307-320.

[52] S. Wdowinski, R. J. O'Connell, On the choice of boundary conditions in continuum models of continental deformation, Geophys. Res. Let. 17 (1990) 2413-2416.

[53] J. Jackson, Active normal faulting and crustal extension, in: M. P. Coward, J. F. Dewey, P. L. Hancock (Eds.), Continental Extensional Tectonics, no. 28 in Geol. Soc. Spec. Pub., 1987, pp. 3-17.

[54] C. Scholz, J. Contreras, Mechanics of continental rift architecture, Geology 26 (1998) 967-970.

[55] P. A. Cowie, A healing-reloading feedback control on the growth rate of seismogenic faults, J. Struct. Geol. 20 (1998) 1075-1087.

[56] K. M. Hardacre, P. A. Cowie, Controls on strain localisation in a two-dimensional elasto-plastic layer: Insights into size-frequency scaling of extensional fault populations, J. Geophys. Res. 108 (10.1029/2001JB001712).

[57] M. Ishikawa, K. Otsuki, Effects of strain gradients on asymmetry of experimental normal fault systems, J. Struct. Geol. 17 (1995) 1047-1053.

[58] M. Goldsworthy, J. Jackson, Migration of fault activity within normal fault systems: Examples from the Quaternary of mainland Greece, J. Struct. Geol. 23 (2001) 489-506.

[59] R. L. Gawthorpe, C. A. L. Jackson, M. J. Young, I. R. Sharp, A. R. Moustafa, C. W. Leppard, Normal fault growth, displacement localisation and the evolution of normal fault populations: the Hamman Faraun fault block, Suez Rift, Egypt, J. Struct. Geol. 25 (2003) 1347-1348.

[60] C. J. Ebinger, J. A. Jackson, A. N. Foster, N. J. Hayward, Extensional basin geometry and the elastic lithosphere, Phil. Trans. Royal Soc. 357 (1999) 671693.

[61] A. Gupta, C. H. Scholz, Brittle strain regime transition in the Afar depression: Implications for fault growth and seafloor spreading, Geology 28 (2000) 10871090 .

[62] T. L. Patton, A. R. Moustafa, R. A. Nelson, S. A. Abdine, Tectonic evolution and structrual setting of the Suez Rift, in: S. Landon (Ed.), Interior Rift Basins, no. 59 in AAPG Mem., 1994, pp. 9-55.

[63] P. Christiansson, J. I. Faleide, A. M. Berge, Crustal structure in the northern North Sea: An integrated geophysical study, in: A. Nøttvedt (Ed.), Dynamics of the Norwegian margin, no. 167 in Spec. Publ. Geol. Soc., Lond., 2000, pp. $15-40$.

[64] J. Dieterich, Modeling of rock friction 1. Experimental results and constitutive equations, J. Geophys. Res. 84 (1979) 2161-2168. 
[65] A. Ruina, Slip instability and state variable friction laws, J. Geophys. Res. 88 (1983) 10359-10370.

[66] S. Kirby, Rheology of the lithosphere, Rev. Geophys. and Space Phys. 21 (1983) $1458-1487$.

[67] D. Kohlstedt, B. Evans, S. Mackwell, Strength of the lithosphere: Constraints imposed by laboratory experiments, J. Geophys. Res. 100 (1995) 17587-17602.

[68] Y. Chen, W. Morgan, A nonlinear rheology model for mid-ocean ridge axis topography, J. Geophys. Res. 95 (1990) 17583-17604.

[69] R. Boutilier, C. Keen, Geodynamic models of fault-controlled extension, Tectonics 13 (1994) 439-454.

[70] J. D. Byerlee, Friction of rocks, Pageoph 116 (1978) 615-626.

[71] C. H. Scholz, The mechanics of earthquakes and faulting, Second edition, Cambridge University Press, Cambridge, 2002. 


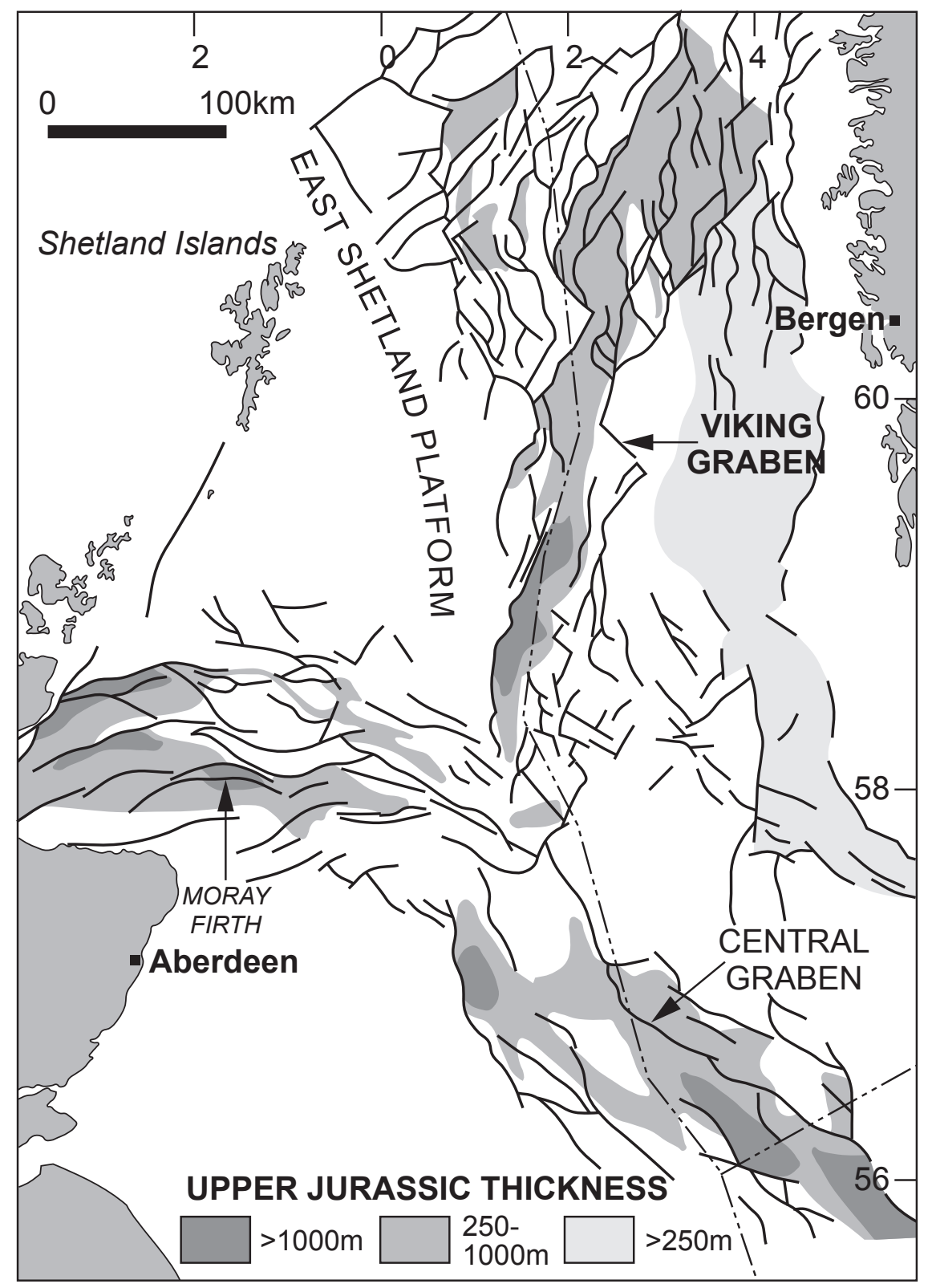

Figure 1 
(a)

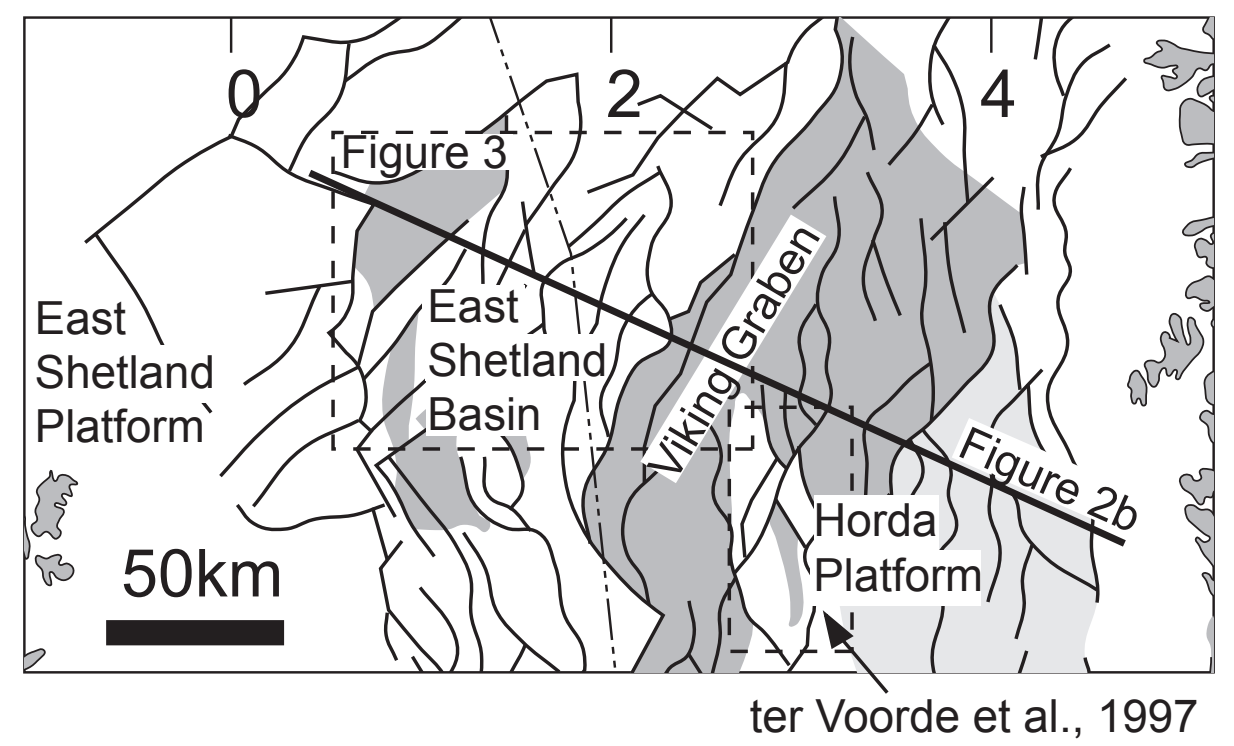

(b)

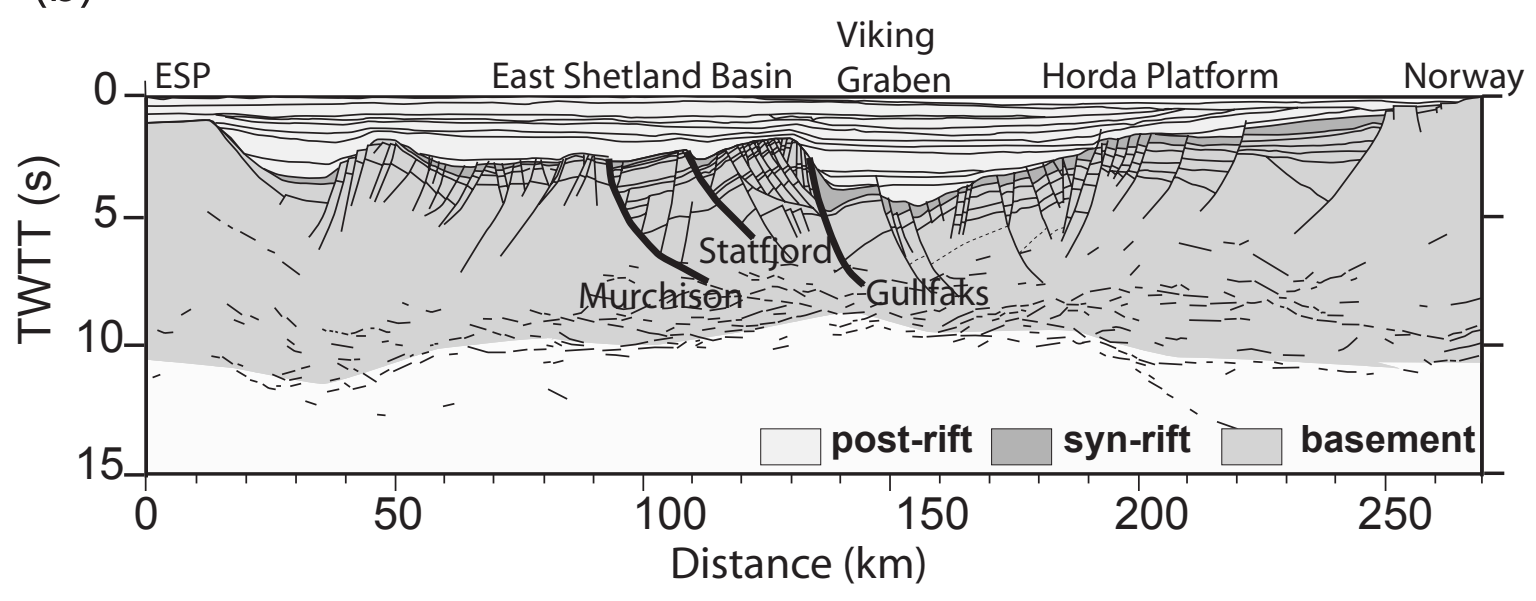

Figure 2 


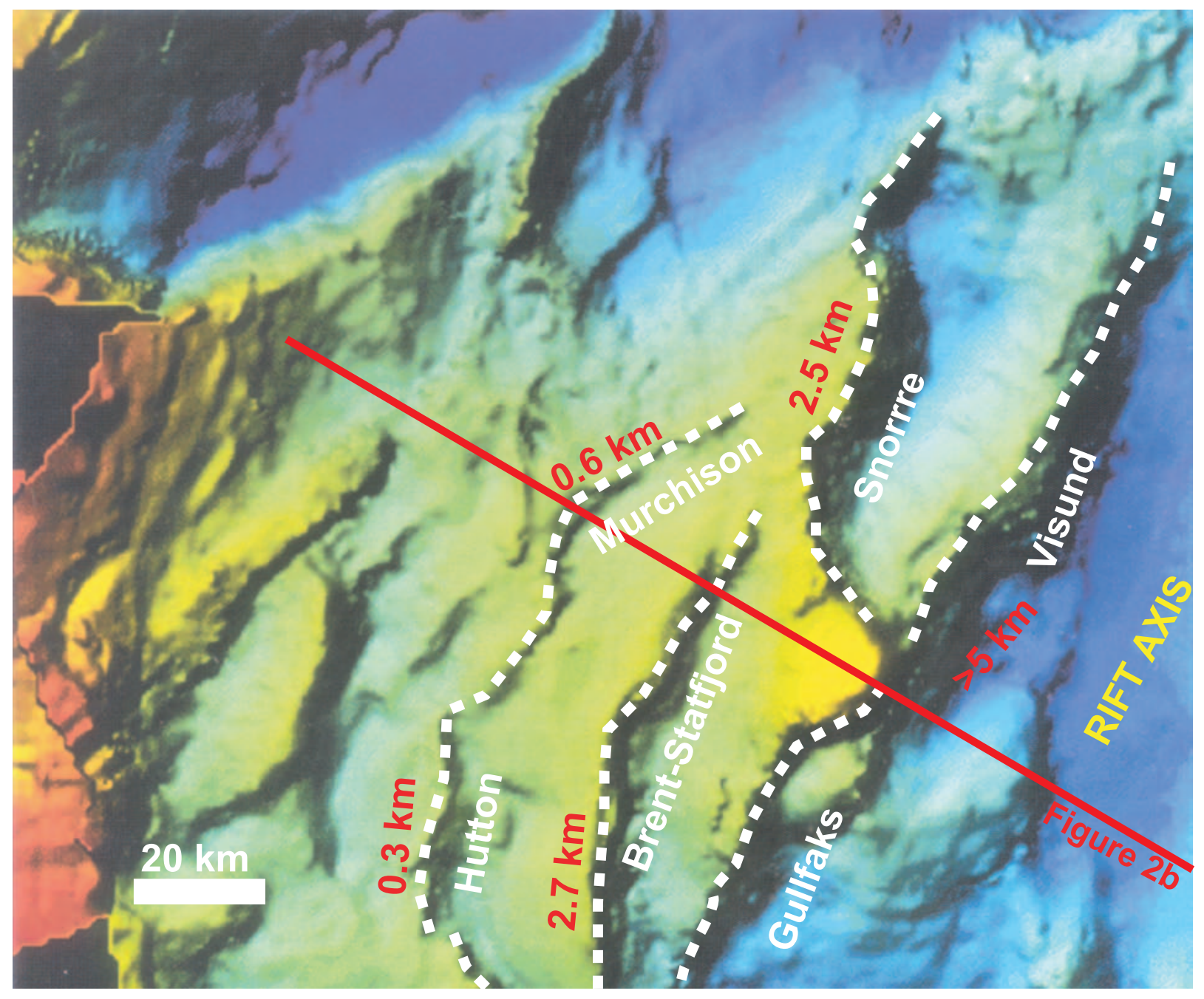

Figure 3 
(a)

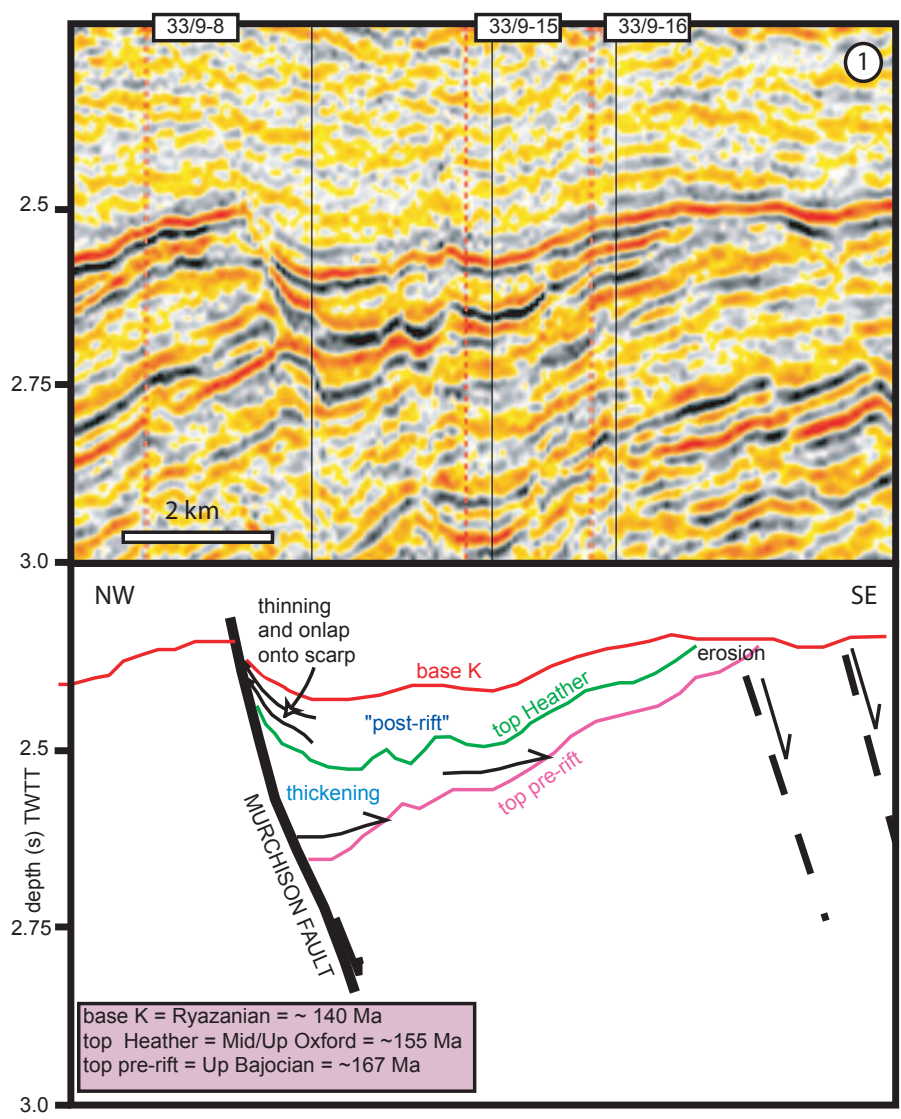

(b)

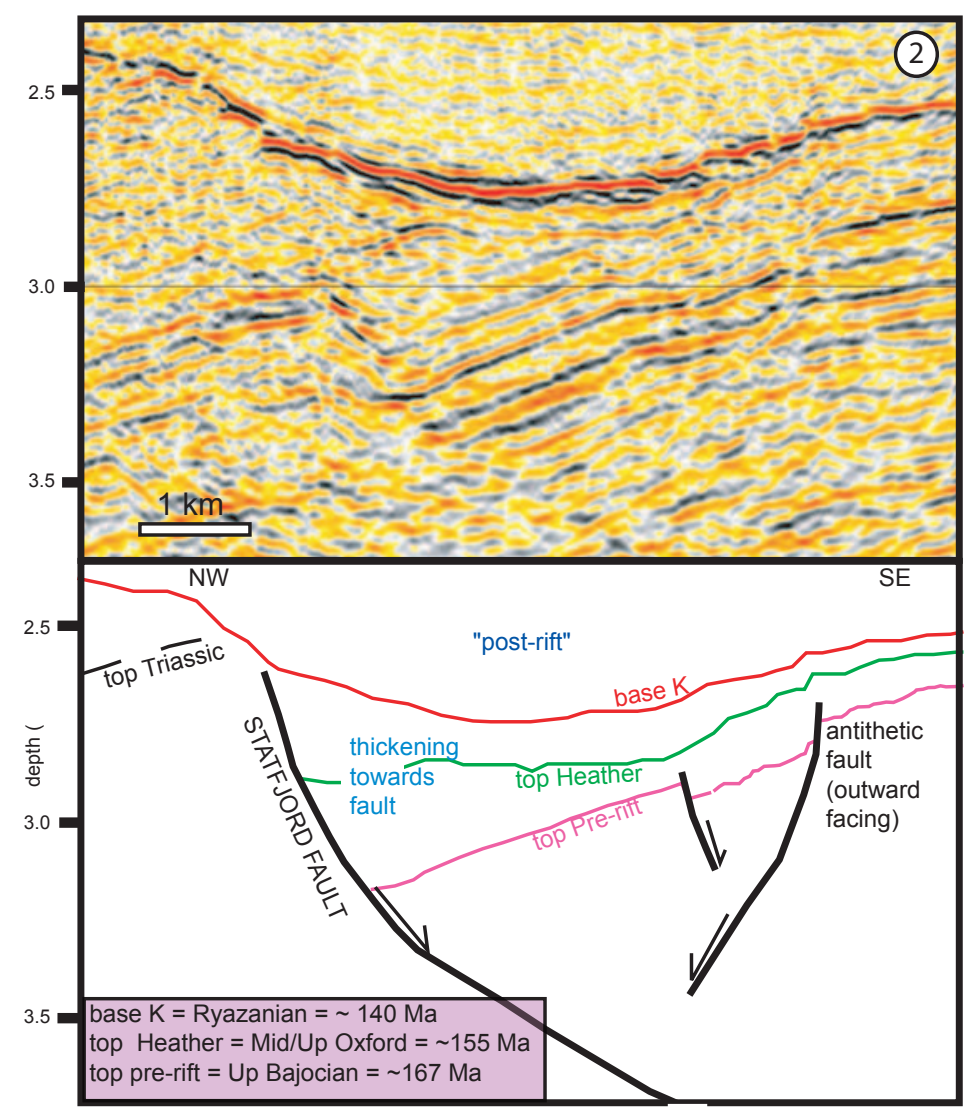

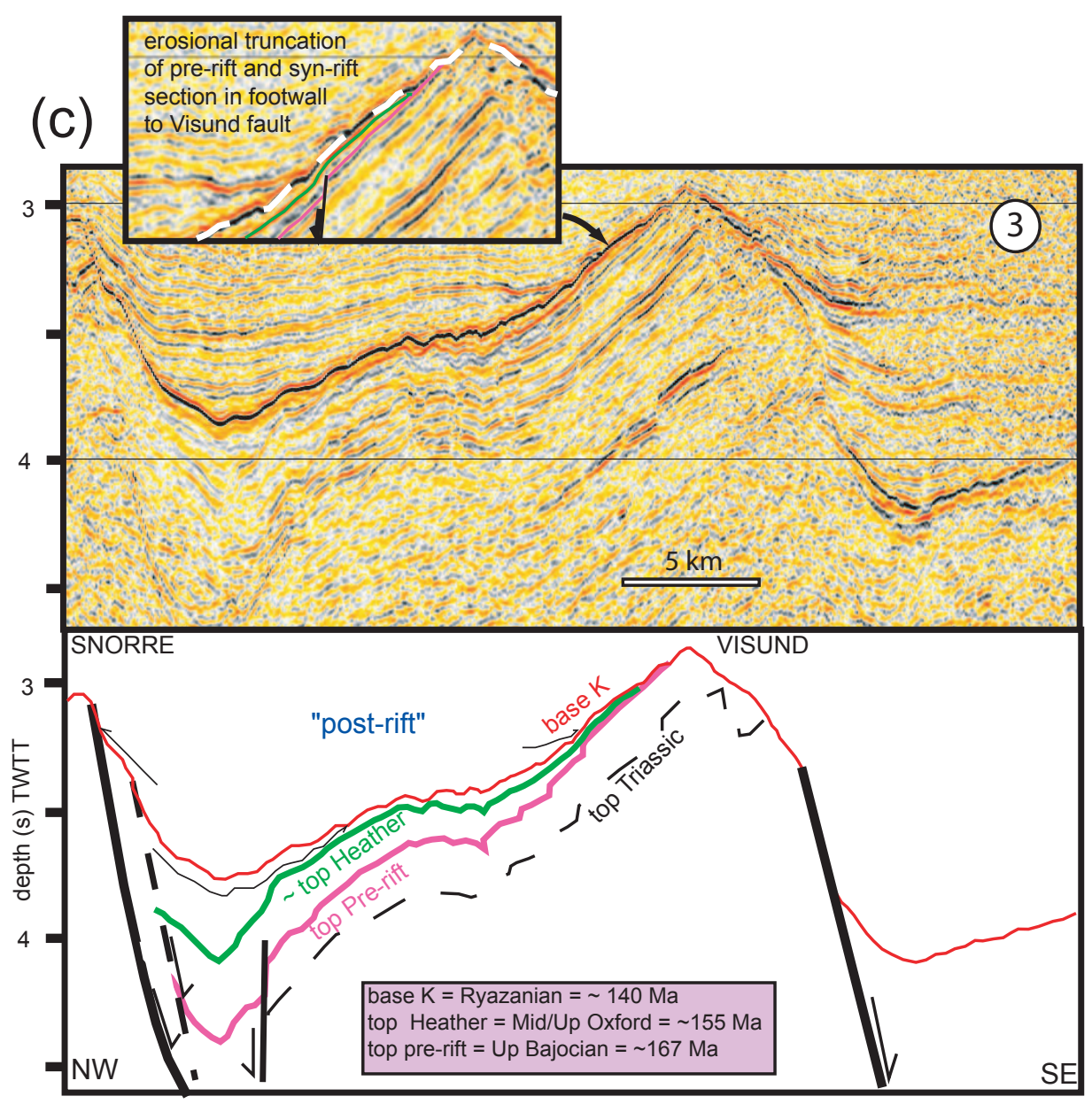


(a)

STAGE 1 Distributed faulting (167-155 Ma)

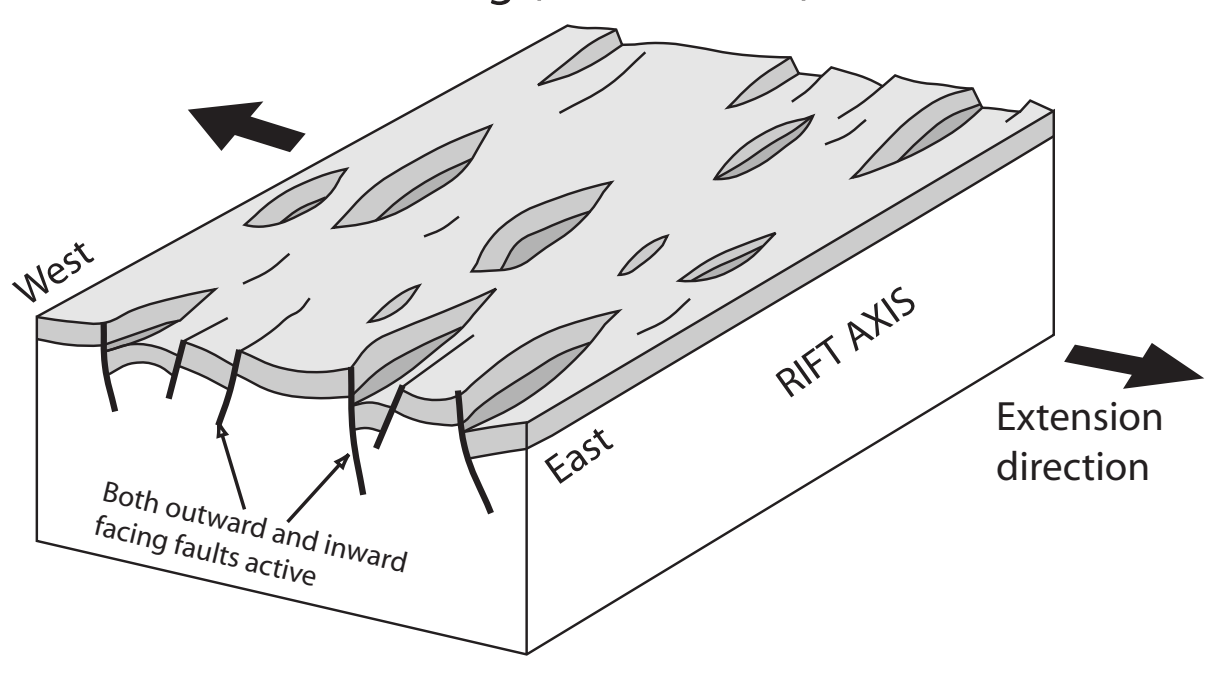

(c)

STAGE 3 Strain migrates

towards rift axis (148-140 Ma)

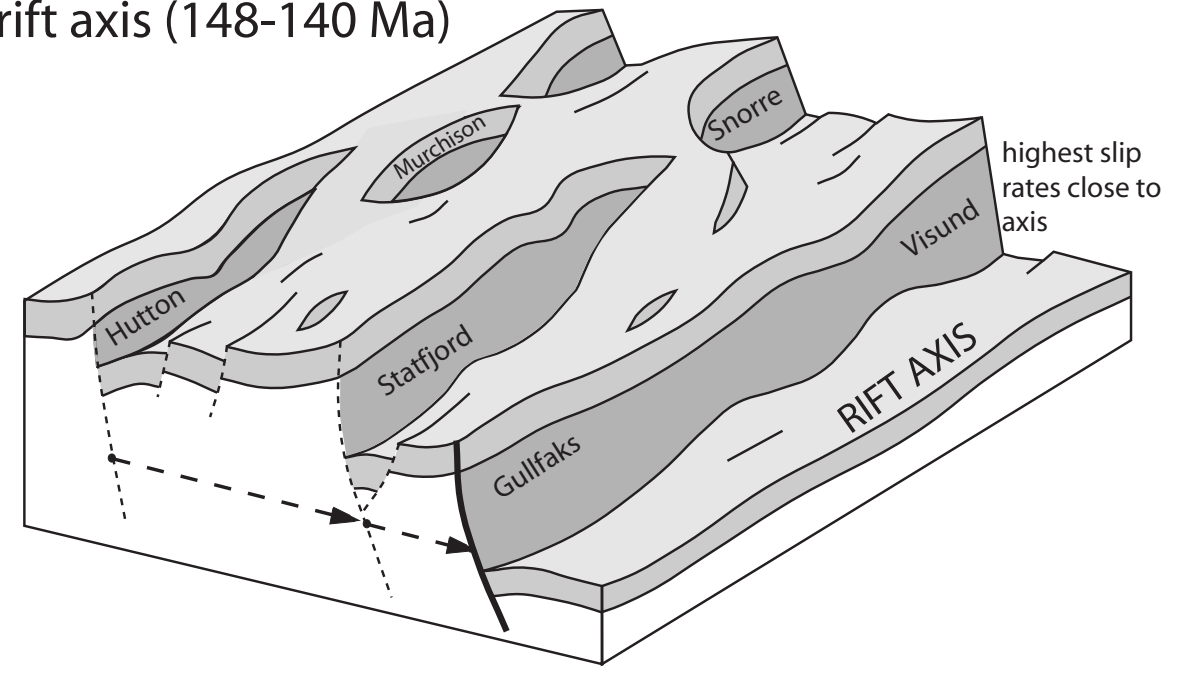

(b)

STAGE 2 Strain localises onto large inward-dipping fault arrays (155-148 Ma)

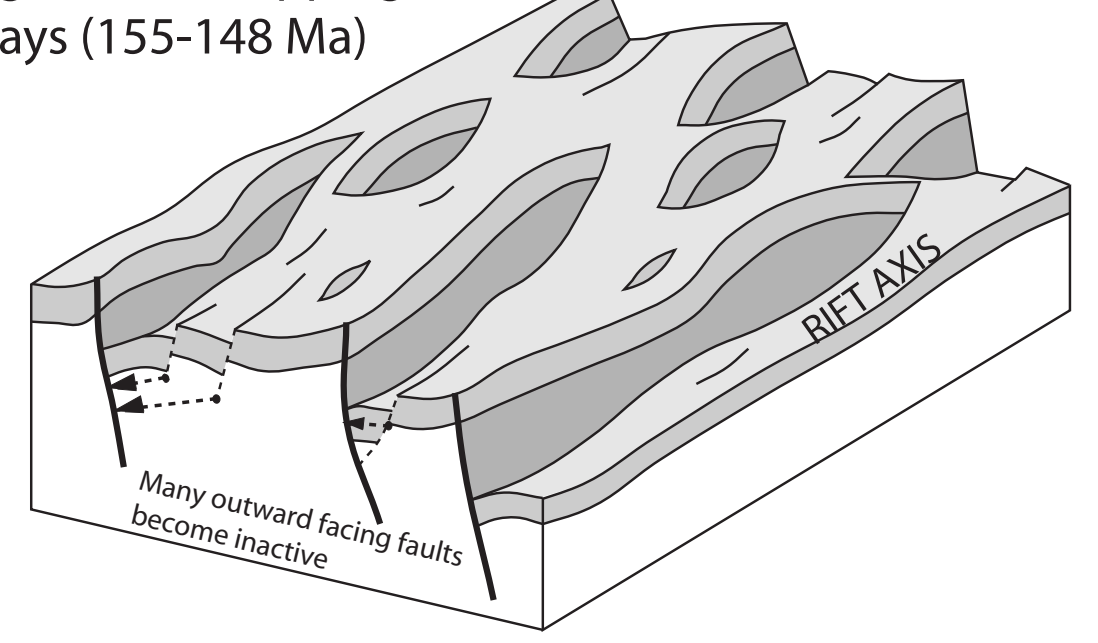

(d)

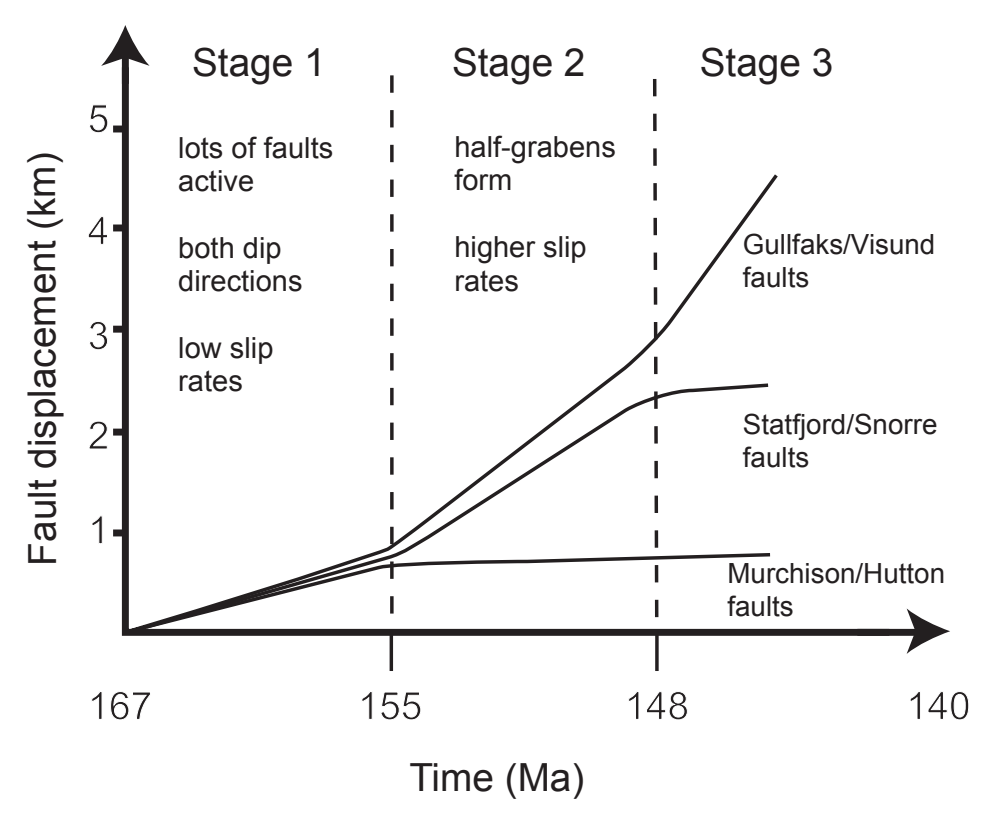

Figure 5 


\section{(a) Plate flexure}
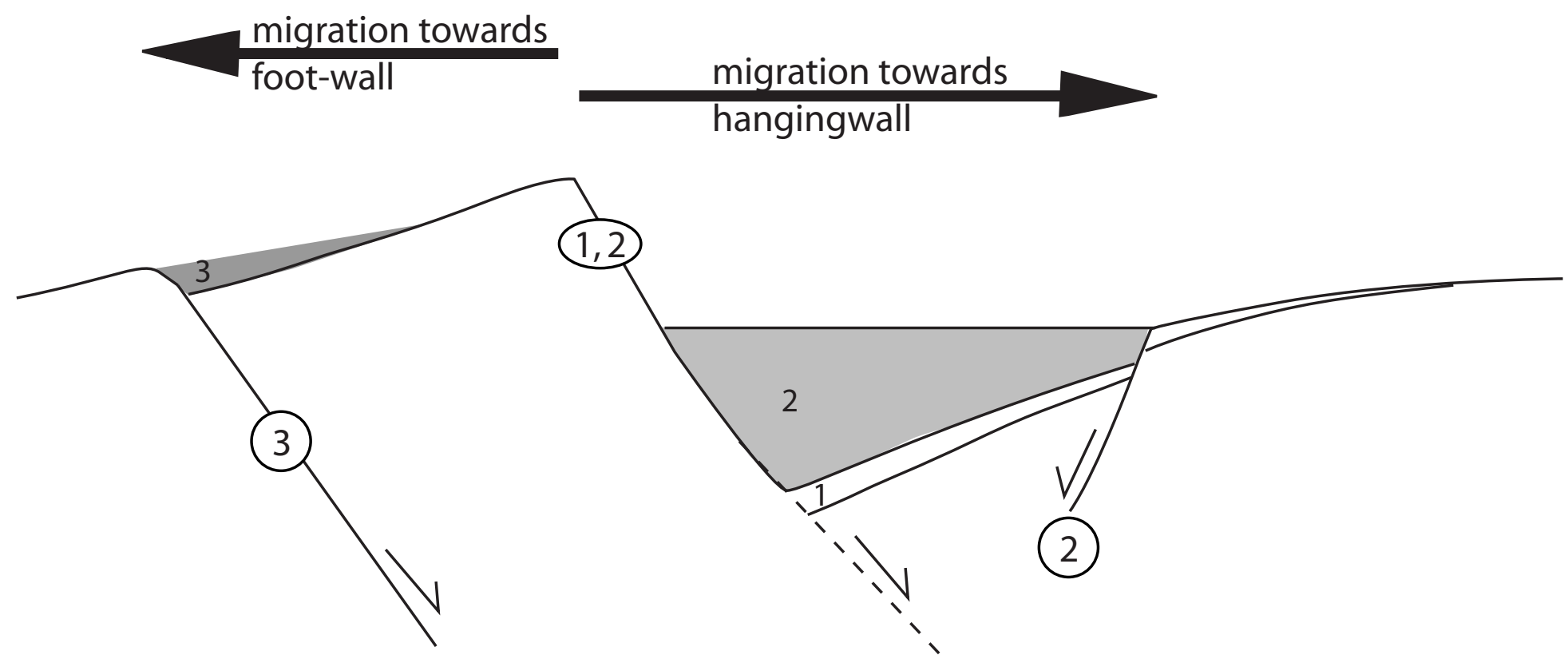

\section{(b) Fault interaction}
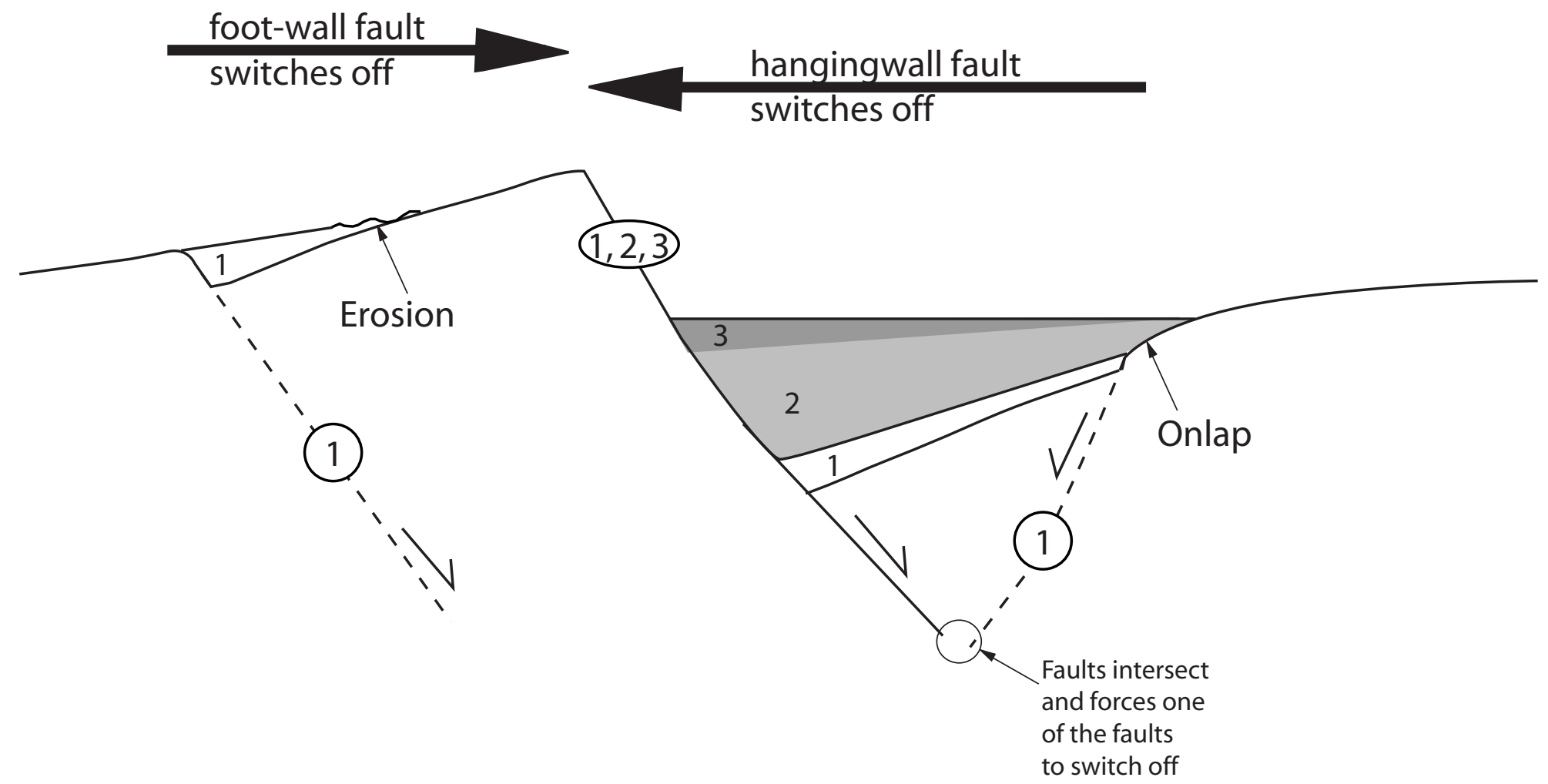

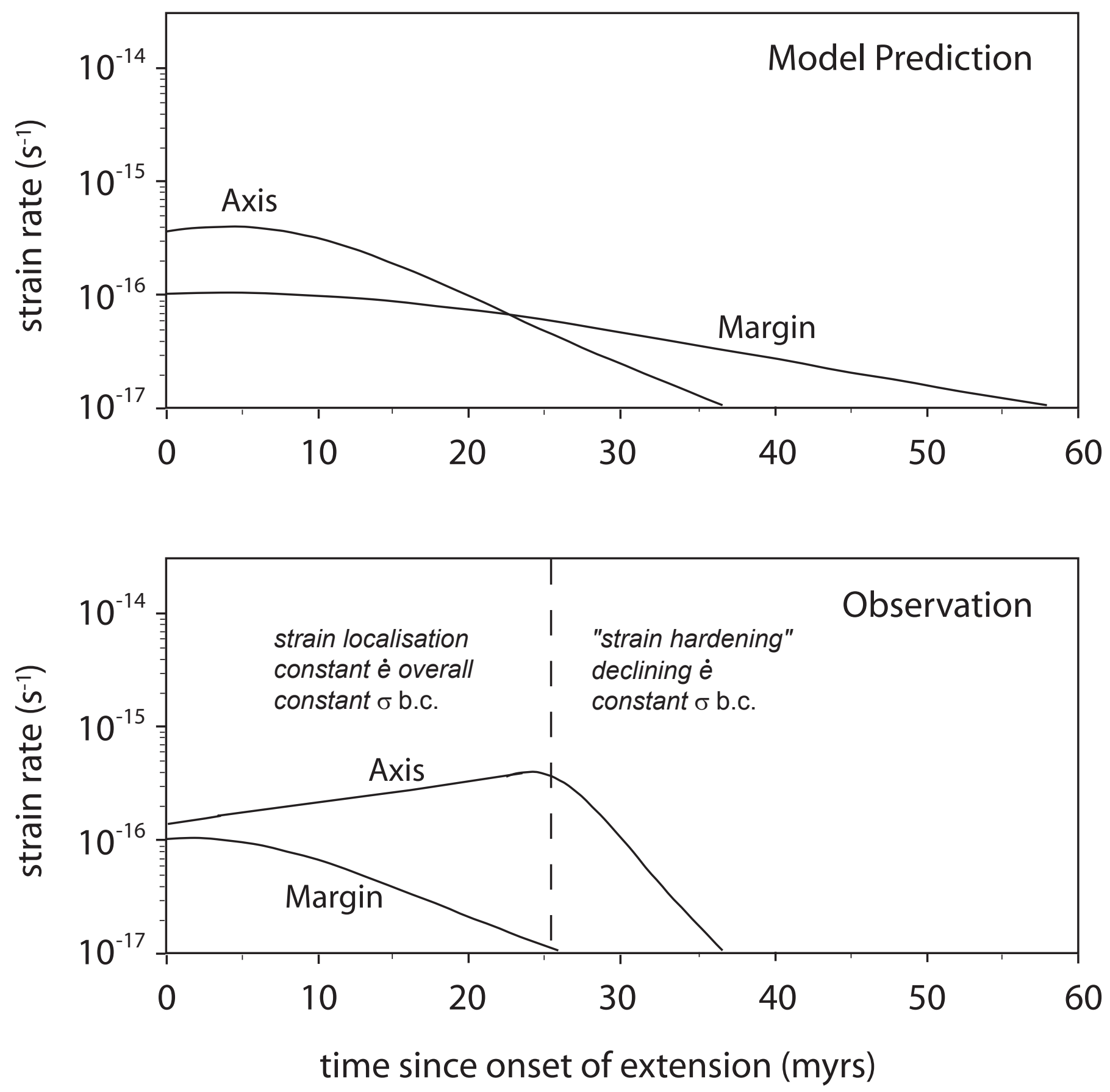

Figure 7 

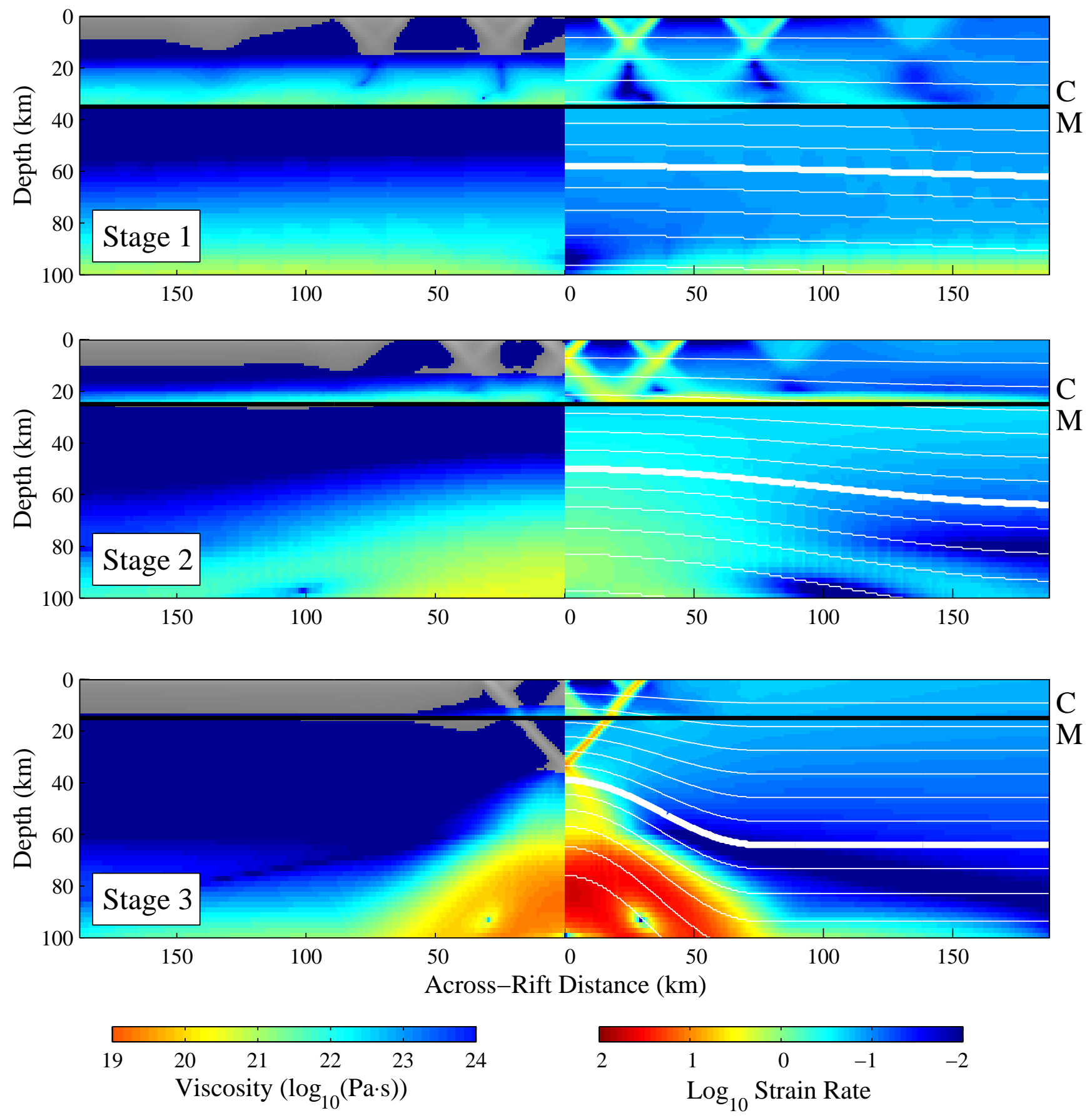

Figure 8 

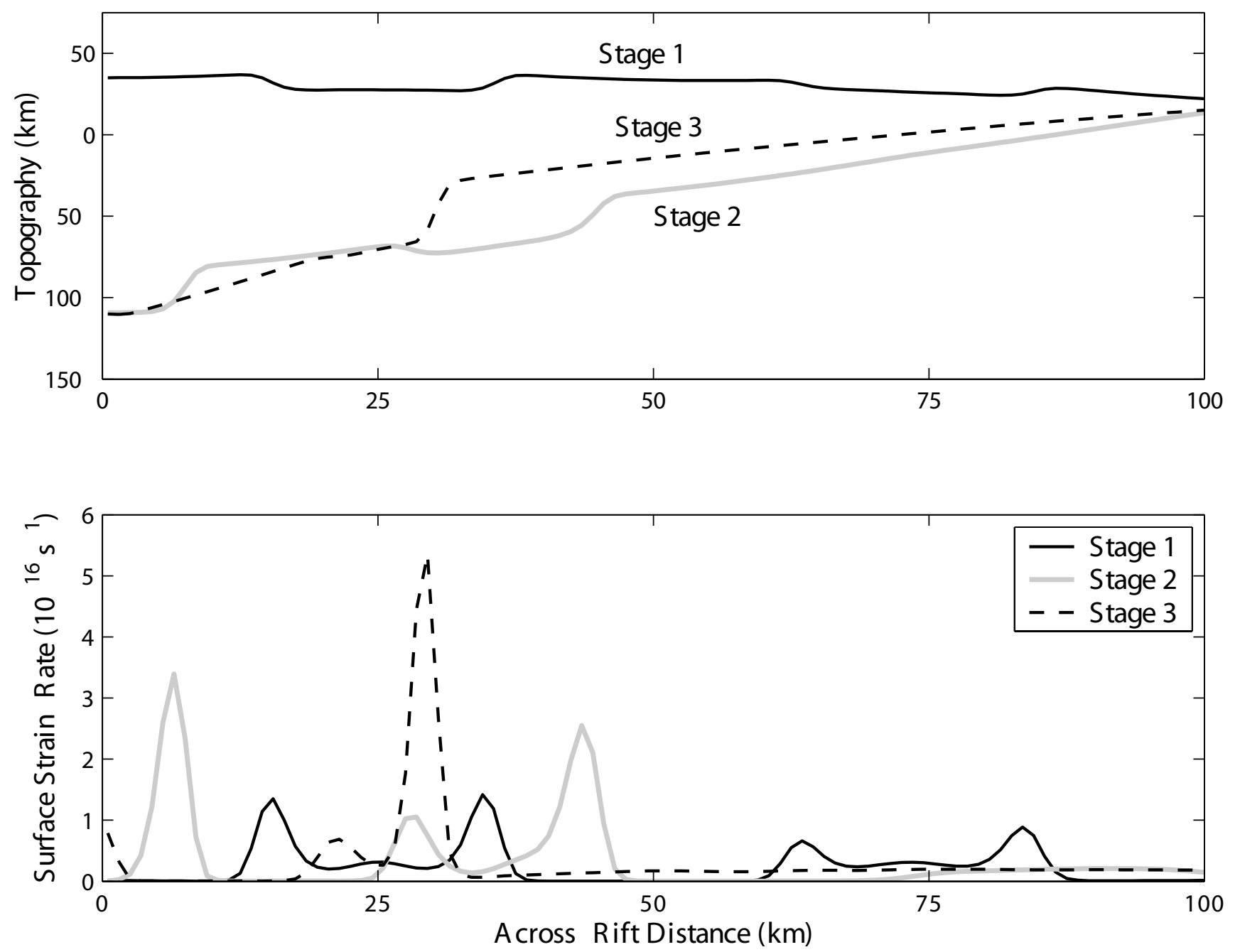

Figure 9 


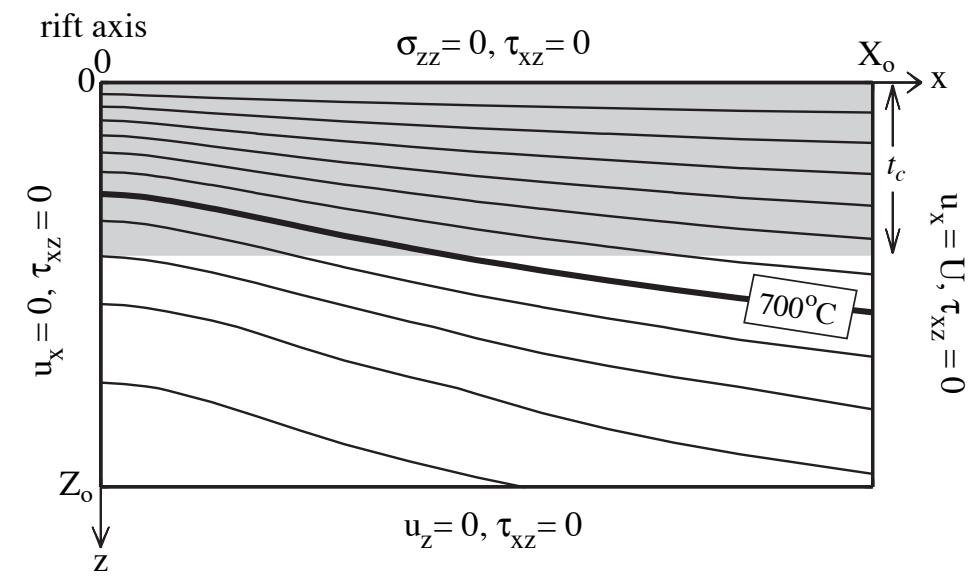

